Portland State University

PDXScholar

1976

\title{
A Model for Teaching Small Group Skills in a Laboratory Setting
}

Larry Ferguson

Portland State University

James Reavis

Portland State University

Follow this and additional works at: https://pdxscholar.library.pdx.edu/open_access_etds

Part of the Social Work Commons

Let us know how access to this document benefits you.

\section{Recommended Citation}

Ferguson, Larry and Reavis, James, "A Model for Teaching Small Group Skills in a Laboratory Setting" (1976). Dissertations and Theses. Paper 1901.

https://doi.org/10.15760/etd.1900

This Thesis is brought to you for free and open access. It has been accepted for inclusion in Dissertations and Theses by an authorized administrator of PDXScholar. Please contact us if we can make this document more accessible: pdxscholar@pdx.edu. 
A MODEL FOR TEACHING SMALL GROUP

SKILLS IN A LABORATORY SETTING

by

LARRY FERGUSON

and

JAMES REAVIS

A research practicum submitted in partial fulfillment of the requirements for the degree of

MASTER OF SOCIAL WORK

Portland State University

$\because .1976$ 
AN ABSTRACT OF THE RESEARCH PRACTICUM OF Larry Ferguson and James

Reavis for the degree of Master of Social Work, presented May 15, 1976.

TITLE: A MODEL FOR TEACHING SMALL GROUP SKILLS IN A LABORATORY SETTING

APPROVAL:

Lynín E. Thompson, Research Advisor

Gordfh Hearn, Dean, School of

Soclal Work

ABSTRACT

The purpose of this research practicum is to present the development, implementation, and evaluation of a model for teaching small group skills. This model was designed for a class in small groups that the authors of this paper taught at Portland State University in the School of Social Work.

In designing this class, the authors were concerned with goals somewhat different than the more traditional goal of imparting knowledge about groups to the learner. The main goal of this class was to teach to students sk1lls in working with small groups. This approach required developing a knowledge base about small groups as well as a way for translating this base into teachable skills. Thus, it became imperative that the class would deal with both cognitive awareness and performance abilities. In order to achieve this, the method of laboratory education was employed. Through the laboratory method, students were given a chance to not only develop a knowledge base in small group theory, but also to prac- 
tice identified group skills in the classroom.

An evaluation was conducted via a pre and post-questionnaire which focused on two areas. The students evaluated the laboratory according to their level of satisfaction with the learning experience. Also, they were evaluated according to their levels of small group skills and any changes in these levels during the laboratory sessions. These changes were measured by a self-perception likert scale and a simulated group response instrument called the Group Situation Questionnaire (GSQ). The results of the Likert scale show that thirteen of fifteen students indicated a positive change in their skill. On the GSQ, only nine students were identified by the instructors as experiencing positive skill change. 


\section{ACKNOWLEDGMENTS}

We wish to express gratitude to our wives, Chris and Kathy, for their patience and support in our endeavor with this practicum. Also, we give our appreciation to Gordon Hearn, whose enthusiasm and insight into the study of small groups has greatly encouraged us. Likewise, Nancy Koroloff deserves our thanks for her help on the evaluation section. The most hearty applause goes to Lynn Thompson, our advisor. Both of us participated in two laboratories that Lynn taught in 1975. These experiences became the impetus for developing this practicum. Lynn encouraged our own independent thinking, academic excellence, and lended freely of his expertise in the area of laboratory curriculum development. 
TABLE OF CONTENTS

PAGE

ACKNOKLEDGMENTS . . . . . . . . . . . . . . . . . . . I1 LIST OF TABLES . . . . . . . . . . . . . . . . . . . . v

CHAPTER

I INTRODUCTION . . . . . . . . . . . . . . . I

II DEVELOPMENT OF THE MODEL . . . . . . . . . . . . . 5

Small Groups .............. . . . . 5

Concept of Skill . . . . . . . . . . 20

Philosophy and Approach of

Laboratory Model . . . . . . . . . . . 23

III DESIGN AND OPERATION OF LABORATORY . . . . . . . . . . 26

Goals of the Lab . . . . . . . . . . 26

Teaching Methods . . . . . . . . . . . 27

IV EVALUATION . . . . . . . . . . . . . 35

Measuring Student Skill Change . . . . . . . 35

Lab Structure . . . . . . . . . . . . 41

Student Feedback .... . . . . . . . . 45

Instructors' Observations . . . . . . . . . 47

V BECOMMENDATION AND CONCLUSION . . . . . . . . . . 53

Recommendation . . . . . . . . . . 53

Conclusion . . . . . . . . . . . . 53

APPENDIX A . . . . . . . . . . . . . . . . . 55 
APPENDIX B . . . . . . . . . . . . . . . . . . 81

BIBLIOGRAPHY . . . . . . . . . . . . . . . . . 98 


\section{LIST OF TABLES}

TABLE PAGE

I Functional Elements of Small Group Skills . . . . . . . 22

II Skill Change During Lab . . . . . . . . . . . 40

III Student Ratings of Instructors' Operation and Behavior In $\mathrm{Lab}$. . . . . . . . . . 4 42

IV Student Frequency of Preferred and Non-Preferred

Exercises . . . . . . . . . . . . 43 


\section{CHAPTER I}

\section{INTRODUCTION}

In this research practicum, the authors will present the development, design, operation, and evaluation of a model for teaching small group skills in a laboratory setting. Our reason for undertaking this practicum topic concerns a personal and professional interest in groups. On several occasions during our graduate training, we have participated in groups for personal growth, as well as educational purposes. Because of these experiences we have developed a desire to study small groups in a more comprehensive manner. Our personal interest coupled with a professional awareness of small group utility has more than compensated for our time and energy in this pursuit.

A large proportion of this practicum's focus will center on the development of the small group skills laboratory (1ab). Another equally important section will cover the implementation and operation of this model. This model was tested at Portland State University in a class offered through the undergraduate department of the School of Social Work. With the authors acting as the instructors, the lab was comprised of twenty students. Their previous group experience consisted mainly of classroom groups and staff committee meetings. Generally, they indicated an interest in learning how groups operate and how they might become more effective in working with groups.

Until recently, many of those who conducted courses on small groups were university-based theorists and scientists. They planned and executed 
their own teaching or training programs while serving as consultants to industry. From their efforts and many others, the concept and design of small group skills labs slowly emerged. (Napier and Gershendfeld, 1973, p. VII). Lately, however, the study of small groups has spread to other professions; e.g., religion, business, and education. In the following passage, Napier and Gershenfeld elaborate on the study and training of small groups:

Through the years, the number of people who required a knowledge of small groups increased significantly, as studying small groups became a legitimate area for widespread study and examination; as the centrality of small groups in a variety of settings became more recognized as a basis for exploring group productivity, decisionmaking, and leadership; and as findings of small group studies and laboratory training were seen to be relevant in areas ranging from increased personal growth to enhance organizational effectiveness.

(Napier \& Gershenfeld, 1973, pp. VII-VIII)

Because of this expansion, the demand for small group training has also increased dramatically. Among the professions, social work has long recognized this demand and its application to practice. Since the Progressive Era (1890-1920), group work has played a prominent role in some social agencies; e.g., settlement houses, YMCA's, YWCA's, and recreational groups. As envisioned by practitioners then, group work focused on social improvement through organized group experiences which often emphasized moral development. It thus became a means for teaching people their own roles in a democracy. In 1923, the School of Social Work at Western Reserve University introduced the first course on group work and, three years later, developed a group work curriculum. Over the next ten years, group work emerged as an area of legitimate study at other schools. However, the practice of group work did not develop as rapidly as curricula 
in schools of social work. In 1935, the National Conference of Social Work created a group work division. But, it was not until 1946 when the conference formally legitimized group work as a specialty with the profession. The years following 1946 witnessed the growth of group work as a separate curriculum and professional entity. Since the mid 1960's, many schools of social work began to exchange the separate methods of casework, group work, and community organization for a generalist holistic approach to social work practice. Such an approach requires the practitioner to intervene with individuals, families, small groups, and groups as large as a communty. (Schwartz, 1971, pp. 1241-1243).

Whether a social worker is a generalist or specialist, his/her knowledge of small groups and skills in working with groups are a necessary part of practice. Margaret Hartford explains this idea further:

This increased demand upon all social workers to have a working knowledge about groups puts new demands on professional education for social work to clarify and teach a body of theory about groups, some theory about the appropriate use of group methods for the achievement of social work goals, and the technical skills of practice in direct work with people.

(Hartford, 1967, p. 50)

Therefore, motivated by our personal and professional interests, we set out to design, test, and evaluate a model for teaching small group skills that could be used for all social workers. We realized the necessity for practitioners to be effective members and leaders in the small group setting. We also realized that the more traditional method of lecturing about group theory in a standard classroom setting was inadequate to help social workers meet the demands they face today. With the words of Hartford in mind, we designed a model that would deal with the need for knowledge as well as the ability to use that knowledge effectively. Thus, 
the body of this research practicum will set forth the development, operation, and evaluation of our model for teaching group skills. 
CHAPTER II

DEVELOPMENT OF THE MODEL

This chapter contains an explanation of the way in which we developed the model for teaching skills in a laboratory setting. Basically, it is an account of the process we used to decide what to teach and how to teach it. This design is a product of our examination of three basic components: (1) small group theory, (2) concept of skill, and (3) philosophy and approach of laboratory model. In order to understand theorles of small groups, we first conducted a review of the literature. Next, we identified our own philosophy of small group behavior. After a close look at the concept of skill, we attempted to integrate theoretical models of small groups with six skill elements which we had identified in our reading. The last phase in the development of the model was an inquiry Into the philosophy and procedures of laboratory education. We identified the goals and mediums in this method of teaching. This chapter will therefore begin with a review of the ilterature.

\section{Small Group Theory}

The purposes for which we conducted a review of the literature were three-fold. First, we needed to gain a general knowledge of the dynamics of small groups and the boundaries of this field of study. Second, from this knowledge, we wanted to be able to decide upon which theoretical perspective we would base the laboratory. This was an attempt to set boundarles by deciding which theoretical constructs would be most condusive to 
our purposes. Third, we reviewed the literature to be able to relate theories of small groups to the teaching of group skills in a classroom setting. The review of the literature thus became a means to an end. Our goal was not to develop or validate particular theories of groups, but it was to examine those theories in order to develop and conduct an experiential laboratory in small group skills.

Why Study Small Groups?

There are a number of reasons why people have spent time and energy investigating small groups. The first reason is pragmatic. Decisions in the political and social arena are made every day in the context of the small group which affect the history and direction of society. The effect of what happens in small groups has a bearing not only upon society-atlarge, but also upon the psychological and emotional sense of well-being of each individual.

The second reason has to do with the purpose of social psychology. It concerns the study of how people affect and are affected by social factors. By studying how people react in small groups, the social psychologist can make generalizations about how people cope and react in other social settings.

The third reason can be found in the goals of sociology. Sociology attempts to understand how society functions by studying groups. Groups are seen as basic building blocks of society. By understanding the variables and characteristics of the small group, sociologists can develop empirically-based theories of how the larger group (society) works.

The fourth reason is that small groups represent a specialized type of a social system. They are not only microsystems within themselves, 
but they represent microcosms of larger groups. Thus, the study of small groups can lead to a general understanding of the processes and characteristics of all social systems. (Mills, 1967, p. 2).

Who Has Studied Small Groups?

In an attempt to answer this question, we have identified two major fields of academic study which have concerned themselves with the study of small groups. First, sociology has taken what is called an external approach. The larger society is the chief focus of analysis. In a biological sense, groups are seen externally by the sociologist as being cells in a larger organism(society). They are not concerned with the interworkings of these cells, only their basic characteristics and functions in the larger society. Thus, sociologists view society-as-groups. In this tradition, there is no focus upon the internal dynamics of the group, but instead there is an emphasis upon the dicotomy between primary and secondary groups. The primary group is characterized by warm, intimate ties with its solidarity based upon sentiments among members. Examples of this type of group are the friendship group, the gang, and the family. The secondary group is characterized by impersonal, rational, and formal relationships among the members. The group is a means to an end. Examples of this range from bureaucracies to the national state itself.

A second field of academic study which has concerned itself with groups is social psychology. In this discipline, the focus is upon groupsas-society. Omstead characterizes this as the internal approach. This approach is concerned with the internal dynamics of the small group. Its method of study is to conduct experiments in order to discover how individuals affect group dynamics. Because the group is the environment in 
which the individual acts and reacts to fellow societal members, the focus of study is to understand the types of interaction and their effect upon the outcomes of the group as a whole. (Omstead, 1959, pp. 19-20). Therefore, the sociological approach is a focus upon the functions and characteristics of small groups, while the social psychological approach is a focus upon the internal interworkings of the group. While the empasis differs in these two approaches, they can complement one another for a general theory of small groups.

How Are Small Groups Defined?

In the external approach, the key definitional characteristic is shared perceptions. Albion Small said:

The term 'group' serves as a convenient sociological designation for any number of people, larger or smaller, between whom such relations are discovered that they must be thought of together . . . a number of persons whose relations to each other are sufficiently impressive to demand attention. (Small, 1905, p. 495)

In this same light, Newcomb (1963) has suggested that shared perceptions, in the form of norms, are essential for a definition of a group.

The distinctive thing about a group is that its members share norms about something. The range covered by the shared norms may be great or small, but at least they include whatever it is that is distinctive about the common interests of group members... They also include, necessarily, norms concerning the roles of group members - roles which are interlocking, being defined in reciprocal terms. (Newcomb, 1963, p. 10)

From the external view of groups, the sociologist defines small groups as being a form of social organization that is essentially goaldirected. For example, Shephard says, "The small group is essentially a mechanism of socialization and a primary source of social order. Therefore, the group is defined by mutual perception and its primary purpose 
is goal attainment." (Shephard, 1964, p. 1)

The internal approach of the social psychologist, De Lameter, has proposed the following definition:

A comprehensive definition of a group can be formulated in terms of the following properties: interaction between individuals, perceptions of other members and the development of shared perceptions, the development of affective ties, and the development of interdependence, or roles. (De Lameter, 1974, p. 39)

De Lameter's definition has come from two sources. First, he analyzed common characteristics which occur in formal definitions of groups. Second, he identified the most common variables utilized in small group research.

His first common characteristic has already been mentioned in the external approach - that is, perception. The second characteristic is from the internal approach; interaction. Bales focuses upon the interactional aspects of the small group in the following definition:

[a small group is] - . any number of persons engaged in interaction with one another in a single fact-to-face meeting or a series of such meetings, in which each member receives some impression of each other member distinct enough so that he can . . . give some reaction to each of the others as an individual person, even though it be only to recall that the other was present. (Bales, 1965, p. 31)

Homans is even more precise,

A group is defined by the interaction of its members. If we say that individuals $A, B, C$, $D$, and $E$ form a group, this will mean that - A A interacts more with B, C, D, and E than he does with $M, N, 0$... who we choose to consider outsiders or members of other groups. (Homans, 1950, p. 15)

The third common characteristic of the formal definitions of groups is Interdependence. From the internal approach to groups, Merton has stated 
that,

the interacting persons define themselves as members, 1.e., that they have patterned expectations of forms of interaction which are morally binding on them and on other members - . the persons in the interaction are defined by others as belonging to the group. (Merton, 1957, p. 22)

As stated earlier, De Lameter identified the most common variables utilized in small group research. Through review of the literature, he designed the following five categories. They are:

1) Affect- This class included all variables which were defined or conceptualized as internal affective states, both positive and negative.

2) Cognition- This class contained all variables or conceptualizations in terms of cognitive states or processes, including beliefs, attitudes, and perceptual varlables.

3) Behavior- All variables which referred to the overt behavior of individuals or groups were classified in this category, including interaction and group achievements through member efforts.

4) Position- This class included variables which dealt with a given individual's relationships to other persons in the group - e.g., variables dealing with one's role, sociometric status, and leadership position.

5) Structure- This class included all variables referring to the location or distribution of parts within a unit - e.g., the distribution of roles. This category is the group-level equivalent of the position class; the positions of the members taken collectively comprise the structure of the group. (De Lameter, 1974, p. 38)

Thus, De Lameter has identified perception, interaction, and interdependence as a common characteristics of groups. He has also categorized common variables studied as to affect, cognition, behavior, position and structure. From this, he has proposed a comprehensive definition which served our purpose in gaining a frame of reference toward a theory of 
small groups. Next, we examined several theoretical models which have been developed to describe and explain the internal processes of small groups.

What Are The Theoretical Models Which Have Been Developed to Account For The Internal Dynamics of The Group?

There are two main reasons why sociologists and social psychologists have attempted to create workable models of groups. Models can organize disparate data into a more coherent whole and their implications can be tested and modified in terms of alternative models.

The Quasi-Mechanical Model

This model views the group much like a machine - an interaction machine. According to this model, small group interaction follows universal and unchanging laws. The laws apply to such things as who tends to speak and to whom they will speak. The model assumes that acts and members can be substituted without substantially altering the system. The aim of the researcher is to discover similarities among small groups. Bales, in particular, has attempted to discover these laws in relation to problem-solving efforts of small groups. (Mills, 1967, p. 11)

The Conflict Model

According to this model, the small group is an arena for an endless series of conflicts. Group experience is conflict. One of the realities of life is that no small group has sufficient resources to fulfill all of its internal needs and external demands. There is a scarcity of position and resources. There are additional strains, such as the fact groups accept and reward certain members more than others. These conditions 
mean that small group experfence is an endless series of conflicts. If certain conflicts are resolved, this resolution will be accompanied by additional strains. This model suggests that no group is conflict-free. If it appears to be so, it is possible that the small group is avoiding facing its real conflicts. (Mills, 1967, p. 14)

The Equilibrium Model

This model sees the group basically as a system that is in equilibrium. Any disturbance, whether external or internal, tends to be counteracted by opposing forces so that the system returns to its original state. Bales gives an example of this.

He proposes that a push toward achieving the group goal disrupts solidarity and consequently tends to be followed by efforts to pull the group together again - and that, since this reconsolidation deflects energy from goal achievement, it tends to be followed by a renewed push toward the goal. (Mi11s, 1967, p. 15)

The Cybernet1c- Growth Mode1

Human groups are information-processing systems potentially capable of increasing their capabilities. Deutsch (1963) assumes that there are members in the group who observe, assess the situation, and act with consequence upon the situation they observe. Self-determination and growth depend upon feedback and action. Group growth is conceived as an increase in capabilities for meeting a wider range of possible demands; such as new signals, new possibilities, and new responsibilities. Thus, small groups are a source of experience, learning, and capabilities, rather than merely being a recipient of resources. (Deutsch, 1963, p. 75) 
This model conceives of a group as resembling a biological organism over time. It forms, grows, and reaches a state of maturity. As it grows, parts become differentiated, each assuming specialized functions, yet these parts are connected and coordinated with each other. Like an organism, the group's internal purpose is self-fulfillment and its orientation to the outside world is self-preservation. The small group follows a natural course of development which is largely determined by its constituent elements (needs, individual personalities, indigenous norms, values, etc.).

This model views a group as a complex phenomenon which has a capacity for change and development. From this viewpoint, interdependence is more than mutual influence. When one element changes, the entire organism changes its nature. (Mills, 1967, p. 13)

The Structural - Functional Model

The small group is seen as a goal-seeking, boundary-maintaining system whose survival is problematical. The group must exercise intelligence and ingenuity, mobilize its resources, and act positively to meet changing demands.

There are four demands which have been identified that the group must meet:

1) Adaptation- When external resources are cut off, the group must be able to find new ones; when current techniques become obsolete or ineffective, it must invent new ones.

2) Goal Attainment- When an impediment appears before the goal, the group must be able to circumvent them; when members become confused, frustrated, or distracted, the group must be able to reorient them and remobilize their resources.

3) Integration- When one part of the group threatens

to destroy other parts, the group must be able to 
check, protect, and coordinate them; the group must bridge the gap between weak and strong, the competent and the inept, and so on; it must create symbols or concepts of itself as a collective unit that unites its subparts.

4) Pattern-Maintenance- In the face of contrary pressures, the small group must be able to sustain its standard procedures, reinforce members' feelings and affective relations, enforce its rules, confirm its values; and it must, for example, be able to "remember" its customs from one meeting to the next. (Parsons, et.al., p. 63)

This model assumes that members will be gratified as the group moves toward attaining its goal. It sees the role of the members as (a) to observe what is happening; (b) to assess the effects of what is happening upon goal attainment and survival; and (c) to take action according to this assessment. Basically, in response to the four demands mentioned earlier, the group members act and learn on behalf of the group - to assure its survival and attain its goals. In this model, the theory of cohesion and activity has the following characteristics: the promise of gratification ties the individual to the group and the members' investment in the group provides it with motivational energy.

These are the models which attempt to make sense out of an enormous amount of data about small groups. For our purpose, we found that the structural/functional and the organismic models were most consistent with our own views of group behavior. These two models provided a framework upon which we formulated our design.

\section{Bridging the Gap}

The previous section is an overview of concepts and theories regarding small groups. As the objective of this practicum was to teach people how to work in groups, we had the task of bridging the gap between theory 
and practice. The field of social work is an applied field of practice. It is not an academic pursuit of knowledge for knowledge's sake. It is essentially an activity that borrows concepts and theories from the social sciences, such as sociology and psychology. Because we needed to select certain concepts that would facilitate practice skills in group work, we have referred to social workers involved with groups, such as Helen Northern and Margaret Hartford. These practitioners have taken certain theoretical constructs about small groups and applied them to the practice and intervention in the small group.

Helen Northern has taken an eclectic approach to group work, drawing on a large range of psychological and sociological concepts. She states what she belleves to be the necessary ingredients for an effective group worker.

It is essential for a social worker to perceive the relationship between individual and group; to have a theory that illuminates the nature of the development, structure, and dynamic processes of the group; to discover the meaning of the ways through which both a group and its constituent members develop and change; and to identify the constellation of methods through which a social worker helps a group achieve its purposes.

(Northern, 1969, p. V)

This statement stresses the internal approach of the social psychologist. Also, the main models which Northern relies on for describing and explaining group behavior are the organismic and structural/functional.

Margaret Hartford has suggested a number of theoretical and practical considerations for the preparation of people to participate in groups. First, as skill implies, there must be a knowledge base. The worker must be able to define their role, have a mastery of group theory, and skill in working with people within a group context. Helen Northern suggests 
the content for the classroom can be divided into the following four areas: (1) phases of group development; (2) processes of group functioning; (3) understanding of intellectual and emotional interactions, roles, norms, style of groups, cohesions, and control; and (4) the effect of the group process upon the individual (i.e., self concept, goals, role, etc.). (Northern, 1969, p. 33). Within this framework, it is evident once again that she is primarily viewing the group internally. From the structural/ functional model, one notes the elements of goal achievement, integration, and maintenance. From the organismic model, Hartford has used the concept of a growing, developing system whose parts are differentiated, yet connected (through interaction and interdependence). (Hartford, 1967, pp. 49-60).

Hartford goes on to suggest possible methods for achieving the aforementioned goals. Teaching suggestions are: (1) case study methods (analysis of records and process recordings); (2) observation through one-way mirrors, films, tapes, and demonstrations; (3) simulated experience (role play, group exercises); and (4) use of the class as a problem-solving clinic for problems students are encountering in their actual work with groups. (Hartford, 1967, p. 57).

In this section, there has been an examination of the definitional characteristics of small groups and an inquiry into the theoretical models. Also, there is reference to the process by which the theory of small groups can be translated into a model for teaching people how to function effectively in the small group setting. The way in which we utilized this transition between theory and practice is more fully explained in the chapter on design and operation of the $1 \mathrm{ab}$. 
Small Group Philosophy of Instructors

Before designing the lab, we realized that its framework and format would be greatly influenced by our own philosophies of small groups. Without a clear understanding of our beliefs and attitudes, we risked potential inconsistencies in formulating the lab. Consequently, one of our first tasks involved defining our beliefs and blending them into a compatible base for the development of the lab. In explaining our philosophies, we explored two key areas of small groups - our views toward small groups themselves and our attitudes toward small group leadership.

To understand our individual philosophies, we will each present a statement of belief about small groups first and leadership in small groups second.

Small Groups:

Larry - I hold a basic faith and trust in groups. I believe that groups can be effective if their members have a sincere desire in achieving tasks and fulfilling individual needs. Inherent in my belief is also a respect for group development. I see group development as a continuum: as a group meets during its life, it evolves through specific phases of development until it ends. I also believe that groups function best with minimal structure from a leader; if structure is needed, then it will emerge from group concensus. What is significant to me about small groups is their movement through various phases of group development to a sense of group cohesiveness. This is the essence of group development for me.

Jim - My philosophy toward groups is that they are basically a potentially effective means to get work done and/or get personal needs met. Having had group experiences of one sort or another all my life, I have been part of both effective and ineffective groups. Many of my experiences have been in groups which I have considered ineffective due to fragmentation, inadequate leadership, or lack of focus upon common goals. Due to this, one of my main interests in small group behavior is gaining a clear understanding of the components which make up an effective group. My definition of success is related to goal achievement, whether the group is task-oriented or emphasizes personal growth. With this in mind, I believe that all groups need some structure in terms 
of goals and tasks. This does not mean that the process of the group's development can be ignored or by-passed. Rather, the structure may change as the group develops, but structure is a vital part of the group's behavior.

\section{Leadership in Sma11 Groups:}

Larry - Because I believe that small groups best function by their own means, I see leadership as basically nondirective. Assuming that a group has set clear, specific goals for itself, I believe that formal leadership needs to be minimal and responsive only when a group member or members request help. I see leadership among members as functional: it is what members do to help the group reach its goals. Functional leadership roles deal with identified problems, needs, and tasks.

Jim - Because of my group orientation, I am most comfortable with a structural, directive leadership style. I have made the mistake in the past of being an autocratic leader and have had to deal with group resistance and anger. Because of my desire for effective use of group resources, I have found that the democratic leadership styles suits me best. I try to give everyone a say about decisions and methods, but I try to provide focus and coordination for the group. Also, I try to be aware of the natural leadership which emerges in the membership. I work with this natural leadership and realize the positive functions of spreading out leadership tasks and roles.

What is obvious from our description is our difference of view toward small groups and leadership style/function. On the surface, this difference indicates potential philosophical inconsistencies and subsequent problems in designing the lab. Yet, it actually became a useful balance for developing the teaching philosophy of the lab. Instead of using one philosophy or another, we blended our philosophies to create a cohesive one.

Sma11 Groups Skills as Developed for Model

Once we had examined our small group philosophies, our next task involved the development of the theoretical framework for the lab. Since each of us has limited group backgrounds, we labored over an adequate 
framework. Our first task was to educate ourselves to the basics of small group theory through readings and our Fall-term methods class in groups. They were rewarding but by no means comprehensive for our needs. With the aid of our advisor and our self-education, we developed a framework which identified six small group functional elements - membership, communication, goals, leadership, norms, and problem-solving. Against these elements, we then chose a developmental model of group theory as the structure around which they would be presented. This framework is an outgrowth of the organismic and structural/functional models of group theory (see Review of the Iiterature).

The significance of these elements rests in their university to various groups. For our purposes, we see them manifest in groups which satisfy our group definition. Using De Lameter's definition of "small groups" as a base, we define"groups" as people who share collective membership, interaction, and interdependence in participation. Whether a group is an encounter, an ad hoc committee, a math class, or a workshop, it will display these elements. Each element is thus a part of a whole which can be examined separately as supporting and contributing to a group's goals, internal maintenance, and development.

Surrounding these functional elements, we view a developmental model of group theory as most applicable to the lab design. It emphasizes a group's development through stages of growth while seeking to attain certain goals. The group itself is seen as a living organism which changes and develops during this attainment. In essence, the lab model focuses on six group elements which individually and collectively aim at goal achievement . 
This framework provided the lab with two distinct advantages. First, it bridged the gap between theory, and practice. After identifying these elements, we translated them into small group skills. Since they can be observed in any group, they can also be practiced and understood intellectually. This perspective thus gave us an opportunity to develop these elements into skills for the lab. Second, because we did not know what specific academic background and/or work experience the lab students would have, we felt that this framework grounded the content to a level which was appropriate for a student starting to learn fundamental group theory and skills. This framework thus offered us an ideal foundation upon which a student could learn small group theory and skills.

\section{Concept of ski11}

Our next step in the development of the lab concerned the design. In this area, we set out a more specific "blueprint" of what the lab would entail than previously discussed. Before developing the detalls of the $1 \mathrm{ab}$, we first defined skill as we saw it apply to small groups. In Webster's Dictionary, "skill" is defined as "the ability to use one's knowledge effectively and readily in execution or performance." A close parallel to this one is Murphy's definition: "Skill is the ability that comes from knowledge, practice, or aptitude to do something well." (Murphy, 1959, p. 32) Thus, we perceived two parts in skill - cognition and performance. Cognition implies that for every skill there is a knowledge component. Performance implies that for every skill there is an identifiable behavioral component of observing its application.

Taking the functional elements of small group skills, we divided them into these two areas. Table I illustrates our understanding of 


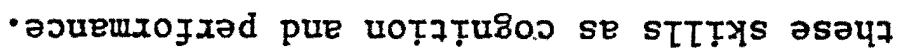


TABLE I

FUNCTIONAL ELEMENTS OF SMALL, GROUP SKILLS

\begin{tabular}{|c|c|c|c|}
\hline & Cognition & & Performance \\
\hline Membership & $\begin{array}{l}\text { Comprehend group selection } \\
\text { and composition to maximize } \\
\text { group attractiveness and } \\
\text { effectiveness for goal at- } \\
\text { tainment. }\end{array}$ & $\begin{array}{l}\text { A. } \\
\text { B. }\end{array}$ & $\begin{array}{l}\text { Select appropriate members } \\
\text { Recognize membership composition factors (descriptive } \\
\text { and behavioral characteristics as well as voluntary or } \\
\text { non-voluntary status) } \\
\text { Identify positive potentials of multiple status and role }\end{array}$ \\
\hline Norms & $\begin{array}{l}\text { Understand and influence } \\
\text { group rules (formal and in- } \\
\text { formal) to facflitate goal } \\
\text { achlevenent. }\end{array}$ & $\begin{array}{l}\text { A. } \\
\text { B. }\end{array}$ & $\begin{array}{l}\text { Identify and clarify normative issues (affective rela- } \\
\text { tionships, power/control, status, achievements, success) } \\
\text { Identify and change positively or negatively variables } \\
\text { which lead to normative conformity. }\end{array}$ \\
\hline Communication & $\begin{array}{l}\text { Know Interpersonal communi- } \\
\text { cation principles in order to } \\
\text { facilitate goal achlevement. }\end{array}$ & $\begin{array}{l}\text { A. } \\
\text { B. }\end{array}$ & $\begin{array}{l}\text { Recognize and use Interpersonal communication skills } \\
\text { (paraphrasing, behavior description, etc.) } \\
\text { Utilize communication patterning (power relationships, } \\
\text { levels of intimacy, size of groups, spartial organiza- } \\
\text { tion, etc.) }\end{array}$ \\
\hline Goal-Setting & $\begin{array}{l}\text { Be aware of the parts of } \\
\text { goals and facilitate their } \\
\text { achievement. }\end{array}$ & $\begin{array}{l}\text { A. } \\
\text { B. } \\
\text { C. } \\
\text { D. }\end{array}$ & $\begin{array}{l}\text { Identify and define potential goal } \\
\text { Clarify potential goal by discriminating between Indivi- } \\
\text { dual and group goals } \\
\text { Select goal(s) } \\
\text { Evaluate goal for level of achievement }\end{array}$ \\
\hline Leadership & $\begin{array}{l}\text { Understand leadership styles } \\
\text { and process for influencing } \\
\text { goal achievement. }\end{array}$ & $\begin{array}{l}\text { A. } \\
\text { B. } \\
\text { C. } \\
\text { D. }\end{array}$ & $\begin{array}{l}\text { Observe and recognize group process and development } \\
\text { Use group resources and initiate group activity } \\
\text { Communicate effectively on an interpersonal level } \\
\text { Apply appropriate style of leadership to developmental } \\
\text { context of group }\end{array}$ \\
\hline $\begin{array}{l}\text { Problem- } \\
\text { Solving }\end{array}$ & $\begin{array}{l}\text { Know dynamics and meanings } \\
\text { of group problems and solu- } \\
\text { tions in order to remove } \\
\text { goal achievement barriers. }\end{array}$ & $\begin{array}{l}\text { A. } \\
\text { B. } \\
\text { C. } \\
\text { D. } \\
\text { E. }\end{array}$ & $\begin{array}{l}\text { Identify and refine problem } \\
\text { offer options for solving } \\
\text { Select solution } \\
\text { Implement solution } \\
\text { Evaluate solution and adjust solution according to } \\
\text { group needs. }\end{array}$ \\
\hline
\end{tabular}


Philosophy and Approach of Laboratory Mode1

Our teaching philosophy for the lab is predicated on experiential learning of small group skills. This learning philosophy emphasizes one's own direct experiences as a means for making generalizations and conclusions. Johnson and Johnson view it as " . . directly experiencing what you [the student] are studying, building your own commitment to learn, and your being partly responsible for organizing the conclusions drawn from your experiences." (Johnson and Johnson, 1975, p. 7) The lab philosophy stresses small group participation around a flexible structure which the students determine for themselves. We believe that this structure should be set by the instructors in a directive fashion to facilitate formal norms and the development of informal ones. Yet, within the confines of the small group, a non-directive leadership role should be assumed by the instructor to permit maximum student participation.

In applying this philosophy, our teaching approach is a mixture of traditional classroom teaching and the Adopt Learning System. (Marcos,1973, pp. 3-4) The first method places much of the responsibility for learning on the teacher, while the student is the passive recipient of this learning. Here, the teacher applies his/her knowledge and skills to a selected subject matter and controls the learning environment according to his/her reactions. This method means that the studentteacher relationship is distant, that the students are treated as a homogeneous group, and that the student's dependency and passivity are reinforced through the learning situation. In short, the traditional classroom environment establishes a low level of student influence and a high level of teacher control. 
The adopt system, on the other hand, increases the amount of student influence and serves to give control to both the student and the teacher. It is a democratic-participatory approach in which both parties influence the content and teaching style of learning. It means that learning can fluctuate between greater student or teacher influence and control. In this system, the teacher and student define the subject area and supply the content. The learning content is designed around the student's issues, needs, and problems, and maximizes his/her skills, resources, knowledge, and experience. During the learning process, the relationship between the teacher and student is maximized while the student is involved in and contributes to his/her learning. It is structured around the individual as a learner while reinforcing his/her independence and resourcefulness. In contrast to the traditional classroom environment, the Adopt System sets a high level of student input and a low level of teacher control. (Marcos, 1973, pp. 3-4)

After examining our philosophies and the above teaching approaches, we realized that an experiential approach offered us two distinct advantages. It assumes that through simulations, exercises, games, role playing, videotaping and analysis, the learner is actively applying and practicing "the cognitive and performance aspects of skills." This compatibility especially helped us assume instructor roles in the lab. It also allowed us to use a teaching method which combined parts of the traditional and Adopt Systems for meeting our expectations of the lab. Essentially, we viewed the experiential approach as a way of merging these two approaches. From the traditional teaching model, we decided that we would select the skills to be taught, supply the mediums for 
learning, and decide on and define what issues and problems should be dealt with. Once these boundaries were drawn, we saw the student's role becoming paramount, as stated under the Adopt System. Through his/her active participation, we saw the student personally involved in his learning through his/her own knowledge, resources, and experiences. Also, we realized that knowledge and skills must be discovered by the student if they are to be meaningful. And last, we viewed this method as reinforcing the student's independence and resourcefulness. 
CHAPTER III

DESIGN AND OPERATION OF LABORATORY

\section{Goals of the Lab}

At last our "blueprint" was taking shape. What remained for us was the formulation of the lab's goals. They would provide the instructors and students with direction and purpose for the 1ab. We thus set out four goals: (1) to develop a theoretical understanding of how small groups operate;(2) to practice identified skills in the following areas of small groups - membership utilization, norm development, communication patterning, goal setting, leadership style, and problem-solving;(3) to gain an understanding of one's own individual style in small groups, both as a member and as a leader; and(4) to experience and understand group deve1opment and group process as they occur in the $1 \mathrm{ab}$.

Goals one, two, and three summarize the design of the $1 \mathrm{ab}$, as we conceived it for the content framework and students. Goal four, on the other hand, is one which did not develop until we had completed our design. Not only were we interested in group development and process as concepts, but also as a phenomenon occurring in the lab itself. We believed that group development and process as concepts are important because of their dynamic effect on group coheston. Although we would focus the lab on skills, we felt that an understanding of group development and process would enhance the relevance and application of these skills. Aside from lecturing students about group development and process, we felt that the best approach to these two dynamic issues would 
be the student's own observations of the lab as it progressed through its own group development and process. To facilitate this development and process, we presented each session in order of increasing skill difficulty: we ordered the skills from easiest to the most difficult. Through such ordering, we hoped that lab students would build a sense of "groupness" which would open an atmosphere of sharing ideas, feelings, and conflicts.

Teaching Methods

The purpose of this section is to present the method by which we organized and presented the educational experiences. We viewed the lab as a place in which students could learn and practice small group skills under controlled, experiential conditions. William Burian, in "The Laboratory in Social Work Curriculum Design", notes, "it is particularly applicable to the development of basic skills such as . . group process skills..." He continues by adding:

As a controlled setting it allows for the sequential introduction of skills, building to increase complexity with provision for monitoring, feedback and adjustment involving little risk for students. That is, students can test and practice specific behaviors with relatively low cost for errors. (Burian, 1976, p. 40)

This controlled setting was also very compatible with our experiential teaching method. It allowed us to work within the university norms (required attendance, term papers, grades, limited meeting times), while offering lab students a chance to practice small group skills and learn group theory.

Continuing with an emphasis upon the concept of skill, we planned educational experiences that would include both cognitive awareness and 
performance abilities. In order to facilitate cognitive awareness, we provided a roadmap of the course for the students on the first day of class. General course objectives, specific session objectives, grading criteria, goals and a bibliography were all distributed on the first day of class. The students were given a chance to question and react to these items. In addition to this, reading assignments which paralleled the weekly topic were given. Also, a term paper was assigned in order to give students an opportunity to integrate the classroom learning with real world situations and experiences. Last, there were several minilectures given during the term in order to help the student tie some of the educational experiences to theory. These were the major areas of emphasis which were used to facilitate the theoretical understanding of groups.

The second aspect of skill, that of being able to perform certain activities well, was organized mainly around the use of simulated/role play situations. Burian discusses the advantages and disadvantages of this educational experience. He suggests the advantages lie in the fact that "it provides a means for creating a facsimile of real social process that is relatively controllable and reproducable." (Burian, 1976, p. 40) Thus, students can practice skills in a somewhat protected environment and learn vicariously. As to the disadvantages, it is clear that simulation/role play situations do not provide the stress and complexity of the real world. With this in mind, the lab experiences can be learning tools, but never substituted for real world experience.

In this 1ab, we used simulated/role play exercises extensively to give students an opportunity to practice and enhance their skills in 
groups. As mentioned earlier, the focus of the lab was largely upon the student as an active, participating member. Participants thus become involved in their own learning process, rather than becoming passive recepients of a certain body of knowledge. Some of the exercises were loosely structured while others contained more specific tasks. At the end of each exercise, there was a debriefing time when participant reactions were encouraged and connections between the exercise and theory were discussed.

The third main focus in organizing the learning experience was the climate of the lab. Climate is used in this sense to include both the intellectual and emotional aspects of the lab. Our presentation of theory was centered around the topic of group development. We saw this as the whole in the sense that each of the skill aspects (membership, norms, etc.) were all contained in the concept of the group as it developed through time. Graphically, we conceived of it as follows:

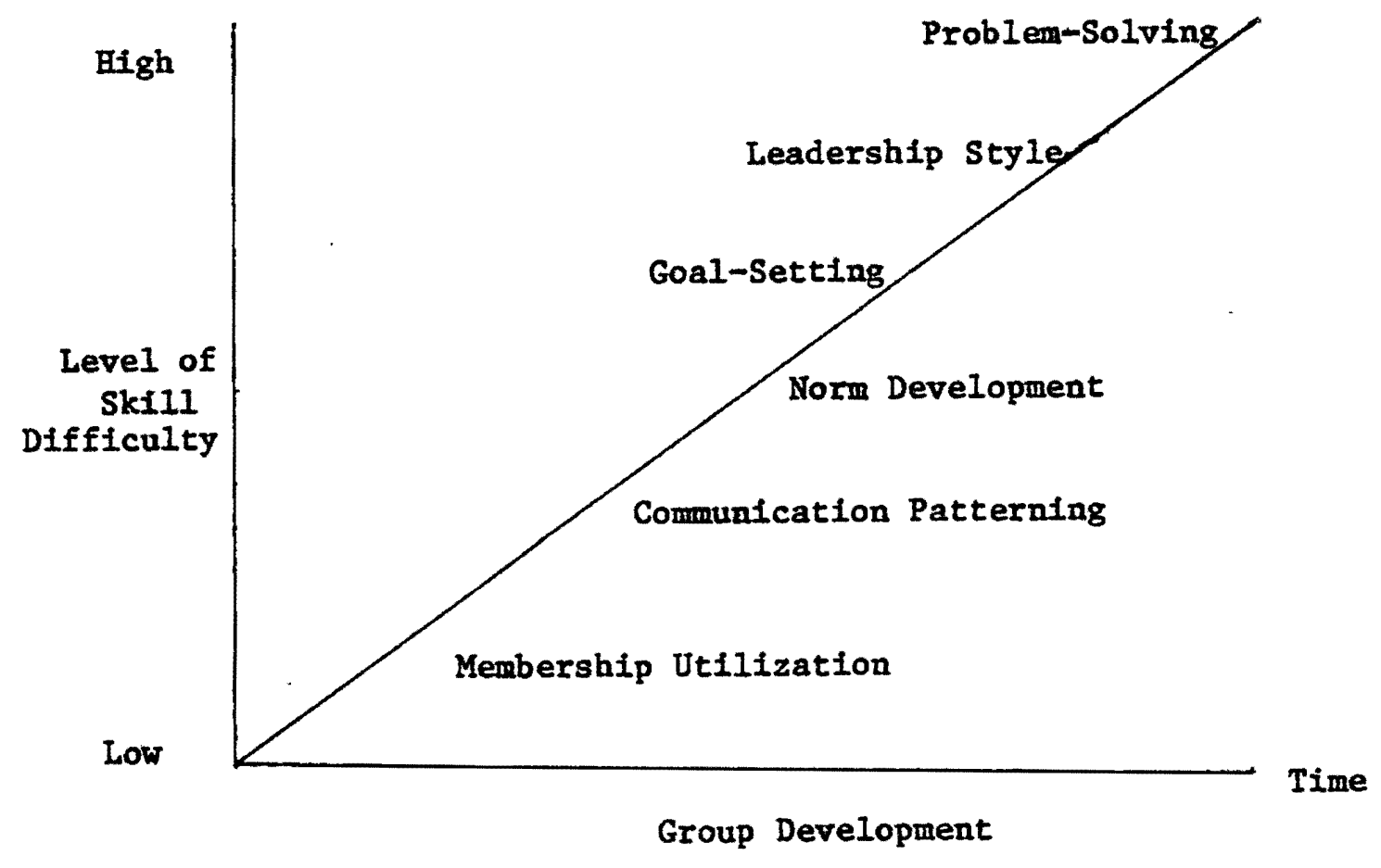


As stated earlier, we not only attempted to structure the theory from the whole to an examination of its parts; we presented the concepts and skills in order of their degree of difficulty or sophistication. We chose membership utilization first primarily to give the participants an understanding of both their unique and common characteristics in the group. This was a focus upon identification of member roles and charactteristics in the group. This was a focus upon identification of member roles and characteristics. We chose norm development second because once identity has been understood, the rules (formal and informal) by which the group operates are helpful to recognize. These are the norms. Third, communication patterns are the means by which the group progresses toward goal achievement. To understand how communication works in small groups helps members interact more effectively. The last three skill areas - goal setting, leadership style, and problem-solving - are all predicated upon an understanding of the previous three skill areas. Thus, we presented the simplest concept (membership) first, and the most difficult (problem-solving) last.

In addition to the intellectual climate, we structured formal and informal norms to facilitate students participating in their own learning. First, we based part of the grade upon active participation and regular attendance. Second, we structured our roles as facilitators instead of teacher/lecturer. Third, we provided flexibility in the exercises and gave the students an opportunity to design and conduct one class session. Fourth, we structured the exercises to encourage interpersonal relationships. For example, in the first class session, we did an exercise entitled, "Getting to know You." Students broke into dyads 
and spent approximately twenty minutes getting to know each other. The first ten minutes were structured to be fairly superficial and the second ten minutes were structured to be more intimate. This was a chance for students to reveal something of a personal nature with one another. An example of our method of teaching in one typical lab session can shed light on how we carried the design of the lab into the classroom setting. On February 9, the lab was focused upon the skill of communication patterning. Our stated purpose for the class was to develop an understanding of how communication patterns affect goal achievement. The exercise was aimed at giving the participants experience in examining communication patterns as affected by individual roles and power relationships. We wanted participants to be able to see how their own role and status affect their group participation. The suggested theoretical background was for the students to read Chapter 1 in Groups: Theory and Experience, by Napier and Gershenfeld (1973), on perception and communication.

Therefore, having read communication in small groups, the students arrived at the television studio. For many of them, it was their first experience with video taping. We sent around an attendance sheet and then gave the students a chance to walk around and observe the various apparatus in the studio. We wanted to desensitize them to their surroundings as much as possible. We then explained that the exercise for the lab would be the group solution of a murder mystery. There would be two groups of seven and two observers for each group. We asked for volunteer observers, split the class into two groups, and asked one group to stay for the taping while the other group went outside of the studio. We sent 
the second group outside so that they would not know the answer to the mystery when their turn came. We then passed the clues to the mystery to the group members. Some group members had more clues than others, but everyone had at least two clues. The time limit for each group was eight to ten minutes. Their task was to decide, 1) the murderer; 2) the place of the murder; 3) the time; and 4) the motive. The clues were as follows:

When he was discovered dead, Mr. Thompson had a bullet wound in his calf and a knife wound in his back. Mr. Barton shot at an intruder in his apartment building at midnight.

Mr. Thompson had virtually wiped out Mr. Barton's business by stealing his customers. The elevator operator reported to police that he saw Mr. Thompson at 12:15 A.M.

The bullet taken from Mr. Thompson's calf matched the gun owned by Mr. Barton.

Only one bullet had been fired from Mr. Barton's gun. The elevator man said Mr. Thompson did not seem too badly hurt.

A knife found in the parking garage had been wiped clean of fingerprints.

Mrs. Scott had been wafting in the lobby for her husband to get off work.

The elevator man went off duty at 12:30 A.M.

$\mathrm{Mr}$. Thompson's body was found in the park.

Mr. Thompson's body was found at 1:20 A.M.

Mr. Thompson had been dead for about an hour when his body was found according to the medical examiner. Mrs. Scott did not see Mr. Thompson leave through the lobby while she was waiting.

Bloodstains corresponding to Mr. Thompson's blood type were found in the basement parking garage. Police were unable to locate Mr. Barton after the murder.

Mr. Thompson's blood type was found on the carpet outside Mr. Barton's apartment.

There were bloodstains in the elevator.

Mrs. Scott had been a good friend of Mr. Thompson and had often visited his apartment.

Mrs. Scott's husband had been jealous of the friendship.

Mrs. Scott's husband did not appear in the lobby at 12:30 A.M., the end of his normal working hours. She had to return home alone and he arrived later. At 12:45 A.M., Mrs. Scott could not find her husband or the family car in the basement parking lot of the apartment building where he worked. 
We ran the groups concurrently with observers focusing on two areas of communication patterning. First, to record the quantity of communication, observers collected data as to who talked and how of ten. Each contribution was tallied for each group member. Secondly, the quality of communication was observed according to whether the contribution was positive (lending to the solution of the mystery), or negative (such as interruptions and sidetracks). The quantity of communication was more accurately charted by the observers than was the quality. The subjective evaluation of positive and negative contributions was understandably difficult for the observers.

During the groups, the discussion was lively and animated. Following the taping of the second group, we played back the tapes of both groups without interruption. Following the playback, we spent thirty minutes in a general discussion and debriefing period. We structured the discussion around the following questions: 1) How does it feel to see yourself on videotape?; 2) What are the results of the observer's data?; 3) What role did you play as a member and how did this affect your communication?; 4) Who were the influential members? Why?; 5) What is the relationship between the number of member contributions and the amount of member influence?; 6) How did your own communication patterns affect goal achievement (solution to the mystery)?; and 7) How would you characterize the style of the communication in your group?

In designing this session, we continued our emphasis upon theory and experience. With the challenge of solving the mystery, participants reported that during their groups, they became unaware of communication patterns and their uncomfortableness of being in front of TV cameras. 
The selection of this exercise was aimed at accomplishing these two goals. Because of the consuming nature of the group task, the participants could act more naturally in a strange, uncomfortable setting. Also, because everyone had clues, everyone had to participate in the group. After the original taping, the members could focus upon the emotional and intellectual reactions via the playback, observer reports, and discussion period.

Therefore, In this lab session, we applied the design to the classroom experience. We included theoretical aspects of communication, a simulated role play exercise, an appropriate learning climate, and a chance for participants to understand the connection between the exercise and the idea of communication patterns within small groups. The video taping proved to be a very effective teaching tool and participants generally reported a high degree of satisfaction with their learning experience. 
CHAPTER IV

EVALUATION

In this chapter, we will present an evaluation of the lab. Essentially, this evaluation will explore four sections: (1) measuring skill change through a student pre and post-1ab questionnaire; (2) relating the results of the lab-structure questionnaire; (3) offering feedback from the students, and (4) interpreting instructors' observations of the lab. The population of this evaluation is composed of fifteen pre and post-lab students. Although twenty students were enrolled in the lab, only fifteen completed both the pre and post-evaluations. The others finished efther one or the other.

\section{Measuring Student Skill Change}

To measure skill changes over a time period, we designed a student questionnaire which was administered at the start and completion of the lab. These pre and post-questionnaires (See Appendix B) include a section which we call the Group Situation Questionnaire (GSQ). The GSQ is modeled from an instrument designed by Daniel B. Wile, which measures leadership in group therapy and related small group settings. (Wile, 1970, pp. 263-273)

It describes six small group sttuations which might occur and asks the student to describe his/her reactions as an imaginary member or leader of this group. Each of these situations aims at a particular skill element - goal setting, membership, communication, norms, leadership, 
and problem-solving - and asks the student to identify specific performance traits which are outlined in Table I under "performance". The Intent of the GSQ is to test the student's small group skills and provide us with a measurement of his/her ability in these skills.

As with any evaluative instrument, the GSQ presented several problems before and after it was administered. We anticipated that the major limitation would be its reliability. Succinctly, we had never tested it for reliability. Although we analyzed it for clarity and coherence, we realized that "bugs" were inevitable. We also realized that because of the subjective responses to the various situations, it would be difficult to make generalizations about skill cognition and performance on a standardized scale. Thirdly, because of the imaginary group setting of the GSQ, it raises the issue of whether student responses would fluctuate or be similar in an actual group situation.

As for the post-administered problems, two of them involved the situation questions. The communication question, number (no.) three, asks the respondent to resolve an argument in an imaginary group. Essentially, it beckons a response which emphasizes effective interpersonal communication skills. Although these skills are fundamental to small group communication, they are not what we originally intended to stress in the lab. Instead, the communication lab session aimed at communication patterning, not interpersonal communication. The result of this post-complication is that we deleted the student communication response from our evaluation because of its inconsistency with our session goal. The second questionnaire problem involved the clarity of GSQ no. two, membership characteristics. Out of fifteen student responses, ten pre 
and seven post-respondents misunderstood or did not respond to this question. We can account for the pre-response misunderstanding because of the question's wording: "Your group has just finished its first session. As you leave the group, you reflect on yourself as a group nember. If you were to describe your group, how would you describe its membership?" Since students were asked to complete the pre-questionnaire immediately after the first lab session, their misunderstanding is easily traced. On the other hand, the seven misunderstandings or non-responses on the post-GSQ is an enigma to us. A tentative explanation is that this question is too ambiguous.

A third problem which limited our post-questionnaire results is time. Lab students were asked to complete the post-questionnaire during the last session. Since it is five pages long, we asked the students to take as much time as they needed (up to two hours) to complete their responses. In contrast to the pre-questionnaire which most of them finished by the second session, all of the students completed the post-questionnaire in sixty to ninety minutes. As we analyzed these results, we discovered that several student's responses were incomplete when compared to their pre-responses. Consequently, the limited time for completion has produced an unforeseen bias in our skill change measurement section. This bias is particularly evident to us in the post-GSQ.

In addition to the GSQ, we included a Likert skill rating scale (See Appendix B) to measure skill change from the start to the finish of the lab sessions. It contalns the six skill elements, which have been previously mentioned, coupled with a cognitive definition of each. According to his/her group experience or personal feeling, the student 
is asked to assess subjectively his/her own skill level based on the skill definitions.

Although we did not foresee any problems with this measurement, we discovered one which related directly to the communication problem described earlier. Because we had changed the skill performance focus in the communication session from interpersonal communication to communication patterning, the communication skill definition thus became inconsistent with our actual lab session focus. As a result, we deleted no. three under the Likert skill change scale from our final analysis. The results of these two instruments were obtained by comparing pre/post scores. In the case of the GSQ, they were scored by counting the number of performance parts a student identified in his/her response against a pre-determined list of skill performance parts. This list was set by the instructors according to the skill performance table (See Table I). Using the pre-score as a base, the difference or sum was determined for each student's skill change for five of the elements. A similar mathematical process was also used to score student skill changes on the Likert scale. The results of these scores are set out in Table II. The results of the GSQ show that $6(40 \%)$ of the students experienced a negative skill change; i.e., they identified fewer skill performances in their pre-GSQ than their post-GSQ. However, this negative must be viewed in relationship to the time bias previously mentioned, which we feel greatly altered the post results. On the positive side, $9(60 \%)$ of the students displayed an increase in their skill performance identification. The Likert scale results greatly contrast the GSQ ones, further challenging the validity of the above results. Here $13(86 \%)$ 
students indicate a positive change in their small group skills while $1(7 \%)$ show a negative change and $1(7 \%)$ show no change. When the GSQ and the Likert are correlated, they show a very low statistical relation. Using a standard correlation formula, we calculated the correlation at .0296 or .03 . We postulate that this very low correlation is precipated by the limited time completion bias of the post-GSQ. There are possibly other factors which contribute to this low correlation, as mentioned earlier, but we feel that this limited time completion bias is the principle cause of this correlation.

The GSQ and Likert scale are significant because they reveal a change in student skill level during the course of the lab. Although the GSQ and Likert scale results vary and show no correlation, they indicate that the lab was successful in facilitating the students' positive skill change. 
TABLE II

SKILL CHANGE DURING LAB

GSQ

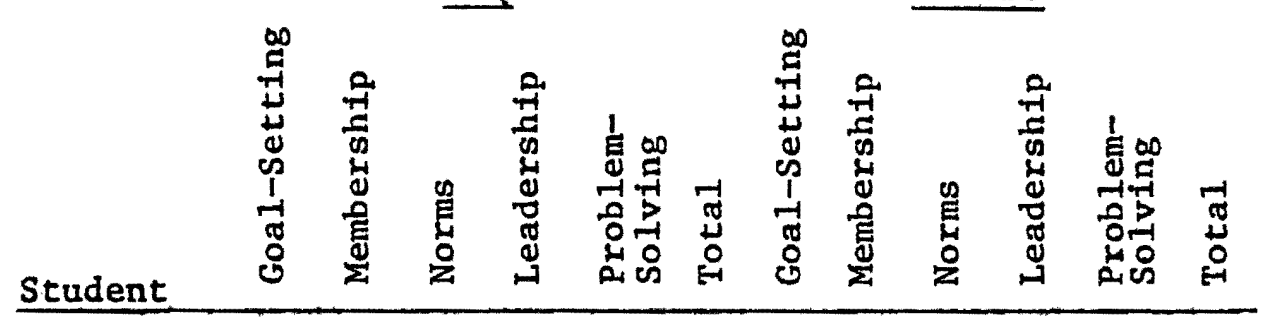

\begin{tabular}{cccccccccccccc}
$A$ & 1 & 1 & 0 & 0 & 1 & 3 & 1 & 0 & 1 & 3 & 2 & 7 \\
\hline B & 0 & -1 & 0 & 0 & 0 & -1 & 2 & 1 & 2 & 0 & 2 & 7 \\
\hline $\mathrm{C}$ & 0 & 1 & 0 & 0 & 0 & 1 & 0 & 1 & 0 & -1 & 0 & 0 \\
\hline $\mathrm{D}$ & 0 & 0 & 1 & 0 & -2 & -1 & 1 & -1 & 0 & 0 & 2 & 2 \\
\hline $\mathrm{E}$ & 0 & 2 & 3 & 0 & 1 & 6 & 1 & 1 & 2 & 2 & 0 & 6 \\
\hline $\mathrm{F}$ & 0 & 2 & 1 & 0 & 0 & 3 & 2 & 1 & 2 & 1 & 2 & 8 \\
\hline $\mathrm{G}$ & -1 & 1 & 0 & 0 & -1 & -1 & 1 & 1 & 2 & 2 & 0 & 6 \\
\hline $\mathrm{H}$ & 0 & 0 & -2 & 0 & 1 & -1 & 1 & 0 & 3 & 3 & 3 & 10 \\
\hline $\mathrm{I}$ & 0 & 0 & 1 & 0 & 1 & 2 & 3 & 2 & 2 & 1 & 2 & 10 \\
\hline $\mathrm{J}$ & -1 & 0 & -2 & 0 & -1 & -4 & -1 & 0 & 1 & -1 & -1 & -2 \\
\hline $\mathrm{K}$ & 0 & 0 & 1 & 0 & 1 & 2 & 1 & 0 & 1 & 2 & 2 & 6 \\
\hline $\mathrm{L}$ & 1 & -1 & -2 & 0 & 0 & -2 & 1 & 0 & 1 & 1 & 1 & 4 \\
\hline $\mathrm{M}$ & 1 & 0 & 2 & 0 & -1 & 2 & 2 & 3 & 1 & 1 & 2 & 9 \\
\hline $\mathrm{N}$ & 2 & 1 & 0 & 0 & -1 & 2 & 1 & 1 & 0 & 2 & 0 & 4 \\
\hline & 2 & -1 & 2 & 0 & -1 & 2 & 1 & 1 & 1 & 0 & 2 & 5 \\
\hline
\end{tabular}


Lab Structure

In addition to the skill change measures, a second part of the post-lab evaluation asked for student responses to three basic areas. They are instructors' operation and behavior, lab teaching mediums, and student reading/writing requirements. These areas were evaluated in order to analyze different means of skill cognition and performance. Under instructors' operation of the lab sessions, no. five, $7(47 \%)$ of the students responded with "Excellent" and $7(47 \%)$ responded with "Good" ratings; only $1(6 \%)$ indicated a "Fair" rating. No. 6 asks the students for more specific responses under instructors' behavior. Table III summarizes these frequencies. (See Page 42).

These responses show that the instructors' overall operation and behavior in the lab was "Good" - 66(50\%), "Excellent" - 32(24\%), "Fair" - 27(20\%), and "Poor" $-8(6 \%)$. The means of these nine operations and behaviors are "Excellent" - 3.6, "Good" - 7.3, "Fair" - 3.0, and "Poor" -.9. Of all the responses indicated, four are noteworthy because of their frequencies under "Excellent/Good" and "Fair/Poor." Student responses to "a" indicated the most favorable aspect of the Iab: 14(93\%) acknowledged that we took an "Excellent/Good" active and personal interest in the lab. Second most frequently indicated under this category is "g". Here 13(83\%) labeled our lab presentation of material - exercises, bibllography, course outline and description - as "Excellent/Good". On the other side of the scale, $6(40 \%)$ of the responses in " $e$ " indicated that were inaccessible to students on the "Fair/Poor" scale. Also, $5(34 \%)$ in " $i$ " categorized us "Fair/Poor" in helping students to identify relationships between exercises and skills. This last response will be 
TABLE III

STUDENT RATINGS OF INSTRUCTORS ' OPERATION AND BEHAVIOR IN LAB

\begin{tabular}{lcccc}
\hline Instructors' Operation \& Behavior & Excellent & Good & Fair & Poor \\
\hline $\begin{array}{l}\text { Takes an active and personal } \\
\text { interest in the lab. }\end{array}$ & $6(40 \%)$ & $8(53 \%)$ & $1(7 \%)$ & 0 \\
\hline $\begin{array}{l}\text { Facilitates student's poten- } \\
\text { tial in 1earning group skil1s. }\end{array}$ & $4(27 \%)$ & $6(40 \%)$ & $4(27 \%)$ & $1(6 \%)$ \\
\hline $\begin{array}{l}\text { c. Stressed important group ski11s. } \\
\text { b. } 2(13 \%)\end{array}$ & $8(53 \%)$ & $3(20 \%)$ & $2(13 \%)$ \\
\hline
\end{tabular}

d. Achieved course objectives as outlined in course description. (one student did respond)

$2(14 \%) \quad 8(57 \%) \quad 3(21 \%) \quad 1(8 \%)$

e. Are accessible to individual students. $3(20 \%) \quad 6(40 \%) \quad 6(40 \%) \quad 0$

f. Were clear and understandable in explanations of group skills and exercises.

$2(13 \%) \quad 9(60 \%) \quad 3(20 \%) \quad 1(7 \%)$

g. Presented 1ab material - exer-

cises, bibliography, course outline and description - in a wellorganized fashion.

$7(47 \%) \quad 6(40 \%) \quad 2(13 \%) \quad 0$

h. Were responsive to student requests. 0

1. Helped students identify relationship between exercises and ski11s. 
further explored later.

The second area identified in the post-evaluation concerns lab teaching mediums. On the overall - quality of the lab exercises no. ane the student frequency responses are tabulated as follows: "Excellent" - 1(7\%), "Good" - 13(86\%), and "Fair" - 1(7\%). Under no. two a and b, the students listed the exercises which they liked best and least. Here is a frequency list of those exercises:

\section{TABLE IV}

STUDENT FREQUENCY OF PREFERRED AND

NON-PREFERRED EXERCISES

Skil1 Exercise "Liked Best" "Liked Least"

No Identified Skill Student-Ied

9

0

Communication

"Murder Mystery"

8

1

Patterning

Problem-Solving

"Desert Survival"

7

3

Leadership

"Three Styles"

5

3

Membership

"Community Proposal"

5

0

Norms

"Lab Norms"

4

3

Introduction

"Getting to Know You"

3

3

Group Development

"Trust in Groups"

3

3

Goal-Setting

"Goal-Setting"

2

2 
As a supplement to the exercises, the TV studio was utilized for two sessions (See Appendix A). For almost all of the students, this medium was a radical departure from the traditional classroom approach. Thus, its effectiveness in learning skills is significant to this evaluation. In no. four, which asks students to judge its effectiveness as a supplementary teaching ald, the students responded as follows: "Excellent" - 6(40\%), "Good" - 5(33\%), "Fair" - 1(7\%), and "Poor" - 3(20\%).

The next focus area involved the student reading/writing requirements. In no. seven, no. eight, and no. nine, the 1ssue of the textbook as a tool for learning was asked. $12(80 \%)$ of the students indicated that If the lab were taught again, it should be continued with about the same quantity of reading. $3(20 \%)$ pointed out that it should be on the reserve library shelf only and that the quantity of reading was too little. As for the quality of the reading, 6(40\%) rated it as "Excellent", $7(47 \%)$ as "Good", and 2(13\%) as "Fair". These questions were easily tabulated because of their distinct categories.

However, no. eleven which asks for a student assessment of the term paper was more difficult to tabulate objectively. Because no. eleven b asks the students for a written, subjective assessment of the paper, there is no discrete data to report. Regardless, we have analyzed these assessments and categorized them according to a "useful learning expertence" or "ineffectual learning experience". Our subjective analysis reveals that ten of eleven students who responded cited the paper as a useful part of their learning. Here are a sample of these assessments: ". . forced us to apply theory to actual situations.","... writing paper helped [me] integrate what was learned in the lab", "... It forced me to re- 
late my own group experience with theoretical concepts we learned.", ". . helped me to really learn the skills.", et.al.

These three areas - Instructors' operation and behavior, lab teaching mediums, and student reading/writing requirements - helped students build a foundation for learning small group skills. In general, the results of this section indicate that this foundation was "built" for students; thus achieving one of the lab's goals.

\section{Student Feedback}

On a more general level, another part of our post-lab evaluation dealt with student satisfaction and feedback. No. fourteen asks the students to rate their general level of satisfaction with the lab. Here the responses showed a large number of students were "satisfied", 11(73\%), while $3(20 \%)$ expressed a level of "very satisfied". Only 1(7\%) rated his/her level as "so-so". There were no responses under "dissatisfied" and "very dissatisfied". In no. three, students listed these new and Improved skills which the lab facllitated (see below). What is especially noticeable about this skill list is the frequency of leadership. The combined leadership score is eleven (11) which is far greater than the others 1isted. Although we do not have any statistical evidence to account for this frequency, we speculate that it is most frequent because of encouraged student participation. During each lab exercise, students leaders were either designated or emerged naturally. We believe that a large percentage of the students held a formal or informal leadership role and thus experienced some skill change as a result. Their participation we belleve accounts for this large frequency. 
Ner Skills

Leadership - 6

Goal-Setting - 2

Membership - 1

Communication - 1
Improved Sk111s

Leadership - 5

Problem-Solving - 2

Communication Patterning - 2

Norms - 2

Goal-Setting - 1

In addition, several students listed aspects of small group dynamics. Although not skills per se, group theory, group observation, and group development were identified by students as "new" and "improved" skills. No. twelve, in essence, gave us feedback on what aspects of the lab might be changed for future use. When asked, "If you were to teach this lab, what things would you change?", the most frequent, unsolicited reply is "more time" (4), during the lab sessions. Fewer small group skills, more use of the TV, and "another text" to Napier and Gereshenfeld are each marked by 2 responses. The remainder of changes are listed once: demonstrations of skills, more practice of these skills, more student focus on speclfic interests, follow-up small group skills' labs, focus on non-verbal communication, more introductory exercises, more structured exercises, more theory, and revised grading system. No. thirteen helped us analyze the beneficial parts of the lab which students felt did not require change. In this instance, the question read, "What things would you not change?". Again the responses covered a wide range. Three of them stand out as significant in terms of greatest frequency: exercises - 6, lab atmosphere -5 , and instructor-student exchange - 4. The remainder of these responses are varied: $T V-3$, room location - 2, size 
- 2, group feeling - 1, student-planned exercise - 1, term paper - 1 , and time of $1 \mathrm{ab}$ meeting -1 .

Most Important of these results is the students' identification of group theory, observation, and development as new or Imporved "skills". This identification is significant because it was a minor lab goal which was not emphasized as frequently as the six skills. Instead, it was dealt with in only one session, "Group Development". In this section, the lab has again shown itself to be an effective means for not only learning or Improving small group skills, but also for understanding group theory.

\section{Instructors' Observations}

The last area this evaluation will cover is the instructors' subjective observations of the lab. In many respects, our observations are similar to the feedback previously mentioned by students. We heartily agree with them about the changes listed above.

As we mentioned earlier, we had never formally been instructors in a university. Although we experienced many new problems as novice instructors for the $1 \mathrm{ab}$, we believe that four were outstanding. One constant constraint on our teaching was the amount of time allowed for the lab. While planning each session, we were continually forced to plan the session not necessarily in terms of objectives, but in terms of avallable time. Generally we planned an exercise for the first hour and then a debriefing for the second hour. On paper, our schedule appeared viable. But once in the lab, time moved quicker than we had expected. ConsequentIy, we generally had twenty minutes or less to debrief an exercise and 
develop a transition from the exercise to a particular session skill. This constraint became especially acute during the two IV sessions. Not only did we have to cram the routine format of an exercise and debriefing into the schedule, but also a time perlod for the TV VIdeo play-back. In order to coordinate lab exercises and time, we devoted more time to scheduling and creating time deadilnes for lab activities. Although this planning necessitated six hours per week of our time, it gave us the needed time to accomplish our session activities.

A second problem we encountered involved grades. We generally felt satisfied with our grading criteria (See "Course Description" in Appendix B). Yet, when we deliberated over grades, we felt very uncomfortable having to assign them. We belleve that our uncomfortableness can be traced to the two roles we assigned to ourselves as lab instructors. In one role, we accepted traditional teaching norms as instructors: we declded what the content and student requirements would be. In short, the instructors directed the students' learning. In another role, we encouraged the students to particlpate and initiate their own learning while being non-directive. Generally we felt most comfortable in this latter role. But, when forced to grade each student, we experienced a contradiction in our roles.

of the three problems we encountered as instructors, the psychological one was the most trying and challenging. Before the formal start of the $1 \mathrm{ab}$, we were aware that we might experience initial anxiety and lack of confidence. Fortunately, our mental preparation helped us resolve these feelings. Aside from them, two others arose which we continually encountered and attempted to resolve. One concerned the issue of 
"pleasing" students and the other involved control and authority.with a particular student. By "pleasing" students, we are referring to our feeling responsible that students understand exactly what we want them to learn. It negates the student's own unique style of assimilating knowledge and makes the instructor solely responsible for his/her learning. We attempted to resolve this issue by reinforcing our philosophical approach to the $1 \mathrm{ab}$ and our roles as facilitative instructors, not parents. On the 1ssue of control/authority, one student continually challenged and tested our bellefs and approach for the lab. He viewed the lab as a group which would best function as an encounter or purely feeling experience. Throughout the first four sessions, we restated the lab's approach for him and explained that we understood what he expected the lab to be and how it ought to function. But, as we concelved the lab design, his notion was incompatible with ours. After examining the dynamics of his idea and persistence, we realized that we were continually "locking horns" with him and not solving this issue. We thereupon decided to shift the thrust of his notion away from ourselves and onto the lab as a group. Such a tact, we hoped, would clarify and settle this 1ssue. What resulted after this happening was that this student was less verbal and challenging to the lab's approach. Although he participated In each session, he seemed to us to marginally accept the lab as presented, but never enthusiastically. Apparently, this tactic quelled his persistence, but not his notion for the lab.

The last problem which we experienced while teaching in the lab concerns insignificant matters. In essence these are minor problems which collectively bothered us in our teaching approach. Although we received 
generally positive student feedback about the TV video sessions as a teaching aid, we feel that its use was too limited. This limitation was underscored by two unsolicited student comments on the post-evaluation under no. four (TV evaluative question); it "... takes a long time to get comfortable enough to learn from experience", and "I need to get over the fear (of the camera) and hesitation felt at first (In the studio)". Because of these comments and others related to the TV, we sense that there was not enough continual TV usage to make it truly effective as a supplementary teaching medium. Also, we felt that the population of the lab (twenty people) was too cumbersome for facllitating debriefings. Almost all of the exercises were performed in small groups of five or ten. Only once did an exerclse require the participation of the entire lab. Because of this large number, we realized that an exercise's effectiveness would depend on the size of the group. The given size was simply too large for an entire group exercise with limited time. Compounding this problem, the hour of the $1 \mathrm{ab}(3: 00$ - 5:00 P.M.) resulted in several students entering sleepy and tired. This problem was observed during one mini-lecture and two debrlefings when two students were observed to be drowsy or napping.

In discussing and analyzing this section, we have presented four problem areas. These problems - time constraints, grading, psychological and minor issues - challenged us as novice instructors. Through post-1ab debriefings and discussion with our advisor, we solved the problems of time constraints, control/authority with one student, and a cumbersome student population. These solutions permitted the lab to continue operating effectively and thus achieve its goal of teaching small group skills. 
In addition to these problems, we experienced many noteworthy events and features of the lab. Many of them have been presented under "student feedback." For us, however, we view the exercises, students' interest, and room as significant contributions to the lab. We feel that the exercises offered students an opportunity to actively learn small group skills as well as contribute to the fun of the lab's operation. Their enthusiasm and interest for almost all the exercises thus gave the lab a tone not often experienced in traditional classrooms. Further enhancing the $1 \mathrm{ab}$, our meeting room at the University provided the students with comfortable sofas, a small coffee table, and well-placed lamps. Thls lounge atmosphere thus provided the surroundings around which the exercises and students combined to facilitate the goals of the $1 \mathrm{ab}$.

The problem of co-teaching the lab was one which we worked at steadily throughout the entire experience. Because we had never worked together before, we realized that communication and feedback would be an important aspect of our own effectiveness. To facilitate our working relationship, we met frequently on both an informal and formal basis throughout the term. We talked about each other's role, the equality of the workload, and our respective presentation styles. In addition to this, after each class, we spent time debriefing with a tape recorder to express our feelings and ideas about how the class went. These tapes proved valuable later because we were able to refresh our memorles about specific class sessions.

This evaluation has included four sections: (1) measuring student skill change, (2) lab structure, (3) student feedback, and (4) instructors' observations. This chapter is significant because it reports empirical 
student/instructor reactions to the lab. The results show that the lab was successful in teaching small group skills to students in spite of several problems. This evaluation not only explains its effectiveness and problems, but also provides a perspective for the recommendation section of Chapter $\nabla$, which follows. 
CHAPTER V

RECOMMENDATION AND CONCLUSION

\section{Recommendation}

This chapter will conclude this practicum by presenting a recommendation for future small group skills' labs and a summary of their potential. This recommendation is based on an assessment of the problems and advantages of the lab. We see an effective lab being composed of sixteen or less members who would meet two days a week, two hours per session. One session would be held in a IV video studio, and the second would be conducted in a lounge room similar to the one in which we met. The meeting time would be in the morning or early afternoon. It would focus on the six small group skills mentioned in this practicum and utilize an experiential teaching approach. It would also emphasize a high level of student-instructor participation in deciding lab requirements or norms (readings, attendance, papers, or grading). Furthermore, instructors could be graduate students in social work or psychology who have a basic understanding of small group theory and skills as well as a desire to work long hours planning sessions. The instructors must also be accessible to members via office hours or telephone. Whether in a university or workshop setting, we view these features as significant to the teaching of a small group skills lab.

\section{Conclusion}

As the demand for professionals whose competencies include small 
group skills increases, the need for an effective.means of teaching small group skills will also increase. One potential way of teaching these skills in through a laboratory. Motivated by our personal and professional interests, we have designed, tested, and evaluated a model for teach-. Ing small group skills in a laboratory. We present this model as an alternative to traditional group work teaching methods because of its uniqueness. This uniqueness takes the small group as a developmental framework and identifies six basic small group skills. It then divides and emphasizes "skill" as cognition and performance. It attempts to facilitate the learning of swall group skills by encouraging a high level of student participation and a non-directive instructor role. These skills are taught around the structure of a "practice classroom" or laboratory. Small group exercises provide a means for practicing these skills, and later debriefings attempt to bulld a transition between performance and cognition. In spite of several problems noted in the evaluation, its benefits to students appear to outweigh its problems. These benefits are manifest in the student evaluafions which show thirteen of fifteen students expressing positive skilf change. We believe that this model offers more distinct advantages to teaching small group skills than the traditional lecture classroom approach. We especially believe that its application is more than appropriate to the training of social workers whose training needs include small group skills. 
APPENDIX A 


\section{SESSION 1 - INTRODUCTION TO COURSE}

Purposes of session:

1) To introduce students to the content and format of the class.

2) To distribute class materials, including a pre-evaluation questionnaire.

3) To provide an exercise in order to acquaint students with the laboratory method of learning.

Outline

Introduction by instructors to class. Discussion of expectations.

10 minutes. (Larry)

Discuss difference between lecture and lab class. Hand out class outline, weekly topics, and reading assignments. Ask for questions on structure of class. 25 minutes. (Jim)

Hand out and explain pre-evaluation. Ask for any questions. 10 minutes. (Larry)

Break

Exercise: Getting to Know You

Objectives :

1) To hasten the development of interpersonal communication within the group.

2) To help establish a norm of openness within a group in which both content and feeling level statements are appropriate.

3) To begin exploring perceptions of one another among the partipants.

Introduce exercise. Ask everyone to get into pairs with someone they do not know. State that they have five minutes to get to know each other in any way they wish. (Jim)

5 minutes go by

Go to the blackboard and ask everyone to call out topics they have been discussing. Write these on one side of the board. (Jim)

Then explain: "For everyone, there are a few people who we can really trust and feel they are truly our friends. These are special people. If this person with whom you have been talking were to become a special friend, what would you want to know about this person. What would be the most important things you would want to know before you could really trust this person? Discuss this with your partner for 10 minutes." (Larry) 
10 minutes go by

Go to the blackboard and ask everyone to call out topics they have been discussing. Write these on the other side of the board. 5 minutes. (Larry)

Ask the group to leave their pairs and return to the group. Open a discussion on the differences between the two levels of interaction. Encourage discussion of their feelings about the two times, the difference, if any, and why, if not. If there was trouble, discuss why. 15 minutes. (Larry and $\mathrm{Jim}$ )

End of class. 


\section{SESSION 2 - GROUP DEVELOPMENT}

Purposes of session:

1) To facilitate students' understanding of how groups develop through time.

2) To identify group tasks which accompany different stages of group development.

Outline

Collect pre-evaluation questionnaires that have been completed at home. Introduce class topic and ask if there are any questions from the reading. (Larry)

Pass out material on stages of group development. Give a mini-lecture on group development. Give definition, dimensions, assumptions, and activities inherent in a comprehensive theory of group development. Relate theory and significance of theory to laboratory setting. 30 minutes. (Jim)

\section{Class Break}

Exercise: The first Stage of Groups - Trust objectives:

1) To give students a simulated experience in which they can identify stages of group development.

2) To focus upon the importance of resolving the issue of trust in the first stage.

Introduce exercise. Ask the class to split into 2 groups of 8 . Describe the situation as follows: "This is a group of people who have come to the local mental health clinic to talk about some of their problems. This is the first meeting. Begin the group in any way you wish." This takes 5 minutes. (Larry)

Let groups run 10 minutes.

After this time, take one member aside from each group and tell them to reveal an intensely personal problem (fantisized). Then give this person the instructions that they should try their best to get other members of their group to do the same.

Let the groups discuss another 10 minutes.

Ask the sub-groups to come together and meet as one large group. Have one member from each group who was coached, discuss what instructions they received. Focus the group discussion around the following questions:

1) How did your group react to the member who revealed his very personal problem? 
2) How did you feel when he asked the group to reveal their greatest problems and fears?

3) How did the revealing member feel as he was "spilling his soul" to the group?

4) What are general rules most groups observe on their first few meetings?

20 minutes. (Larry and $\mathrm{Jim}$ ) 


\author{
SUMMARY \\ STAGES OF GROUP DEVELOPMENT
}

\title{
Stage I
}

This is a formative stage for a group. During this period, members are becoming acquainted with each other. They are testing for their own acceptance in the group, and are working on developing trust relationships with others. They seek orientation, and there is information givIng and receiving related to this. They are beginning a search for meaning in the group, and are dependent on each other and on the leader for help in this search. Members tend to enter new situations with feelings and behavior characterized by uncertainty, anxiety, tension, self-consciousness, and non-commital behavior, and are therefore generally fairly polite and superficial with each other. They tend to avoid conflicts, and generally do not feel sure enough to express their feelings much or deal with the feelings of others.

\section{Stage II}

Once members feel accepted and included in the group, they begin to have enough trust and confidence in each other that they feel free to assert themselves as individuals. This includes sharing opinions, ideas and feelings, and it inevitable results in some conflicts. Sometimes these conflicts are expressed in the form of disagreement between individuals; sometimes the expression is more in the form of rebellion or general dissatisfaction with the group. Thus, members are moving from a stage of dependence to independence or counterdependence. Not only do fights emerge from this move, but also communication patterns are developed as individuals establish roles for themselves in the group. As members criticize and evaluate each others' ideas, decision-making patterns emerge in the group, and members begin to deal with each others' feelings as well as with the task of the group.

\section{Stage III}

Once the group has survived the difficulties of Stage II, tensions begin to release and a type of catharsis takes place. Feelings of cohesiveness and solidarity develop in the group, and members' emotional needs are recognized and dealt with by the group. Members express affection and feeling for each other, and an interdependence among members develops. This stage is characterized by productivity, goal attainment, and establishment of group norms. All is not necessarily roses from this point on, however, for as the group continues to grow and function, new problems will come up which the group will have to deal with. The initial feeling of enchantment of this stage may turn to disenchantment for a while until the group can resolve its conflicts and reach new levels of cohesiveness and consensus. 


\begin{tabular}{|c|c|c|c|c|c|c|}
\hline Northern & Schmuck & $\begin{array}{l}\text { Parsons \& } \\
\text { Bales }\end{array}$ & Schutz & Luft & Tuckman & $\begin{array}{l}\text { Vinter, } \\
\text { Sarr1 \& } \\
\text { Galinski }\end{array}$ \\
\hline Orientation & $\begin{array}{l}\text { Acceptance, } \\
\text { Inclusion } \\
\text { Membership } \\
\text { Trust }\end{array}$ & $\begin{array}{l}\text { Information } \\
\text { Giving \& } \\
\text { Receiving }\end{array}$ & Incluston & Dependence & Forming & Origin \\
\hline $\begin{array}{l}\text { Exploring } \\
\text { and } \\
\text { Testing }\end{array}$ & $\begin{array}{l}\text { Influence } \\
\text { Patterns; } \\
\text { Formation } \\
\text { of Tasks } \\
\text { and Main- } \\
\text { tenance } \\
\text { Communica- } \\
\text { tion }\end{array}$ & $\begin{array}{l}\text { Oplnions } \\
\text { given and } \\
\text { criticized; } \\
\text { Evaluations } \\
\text { and dect- } \\
\text { slons made }\end{array}$ & Control & Independence & Norming & Formation \\
\hline \multirow[t]{4}{*}{$\begin{array}{l}\text { Problem- } \\
\text { Solving }\end{array}$} & $\begin{array}{l}\text { Producti- } \\
\text { vity Goal } \\
\text { Attainment }\end{array}$ & $\begin{array}{l}\text { Tension } \\
\text { Release. } \\
\text {-positive } \\
\text { feelings; } \\
\text {-solidarity } \\
\text { develops; } \\
\text {-emotional } \\
\text { needs dealt } \\
\text { with }\end{array}$ & Affection & Interdependence & Storming & $\begin{array}{l}\text { Intermediate } \\
\text { Phase I }\end{array}$ \\
\hline & $\begin{array}{l}\text { Flextble } \\
\text { norms; se } \\
\text { self } \\
\text { renewal }\end{array}$ & & & & Performing & Reviston \\
\hline & & & & & & $\begin{array}{c}\text { Intermediate } \\
\text { Phase II }\end{array}$ \\
\hline & & & & & & $\begin{array}{l}\text { Maturation } \\
\text { Termination }\end{array}$ \\
\hline
\end{tabular}




\section{SESSION 3 - MEMBERSHIP UTILIZATION}

Purposes of session:

1) To develop an understanding of the importance of selection and composition of group membership.

2) To foster an awareness of the unique characteristics of each group member.

3) To show how member characteristics can maximize individual and group goal achievement.

Outline

Exercise 3 - Multiple Memberships

Objectives:

1) To experience the conflict of multiple memberships.

2) To understand the conflicts of representative memberships in a familiar community setting.

Introduce the exercise and ask for 4 volunteers. Give them their leadership roles and ask them to stand to one side while the situation is described. (Larry)

Describe the situation as follows: "The setting is a surburban community in the Midwest; there are 30,000 inhabitants. The community is conservative and incomes are above the national median. The situation is that an anonymous benefactor feels there is a need for sex education in the community. Such education has never been a part of the budget; the benefactor will donate $\$ 10,000$, which would be sufficient for an excellent program - the community will determine the program. He would like to see such a program instituted this year, but there is a stipulation that we must let him know our decision at the end of the month. If we agree, the benefactor has made the money available immediately. If not, he has made plans to use the funds for a project in another community. We have called this public meeting today because it is the last day of the month. The Chairman of the Board of Education will take the decision made today to the Board as an expression of the community's desire." (Larry)

Pass out roles to each of the class members. (Jim)

Then say: "We have chosen 4 leaders to hold preliminary group discussions. They are the High School Principal, the Executive Director of the Mental Health Association, the President of the P.T.A., and the President of the Chamber of Commerce. The purpose of these preliminary sessions is to air your feelings about the proposed sex education program. Also, each group is expected to reach consensus on a position. The leaders should try to pick people who might agree with their views on the proposed program." (Larry) 
Have each person read their role aloud.

Have the 4 leaders pick the members they want in their groups. 5 minutes.

Begin the preliminary sessions - explain that if consensus is reached, the small groups should plan their strategy for the full community meeting after the class break. Tell them they have 20 minutes.

20 minutes go by

\section{Class Break}

Introduce the general meeting. Stress that a decision must be made today. "The meeting will begin with the Chairman of the Board of Education as the chairperson of this meeting - you have 30 minutes and you may use it in any way you wish." (Jim)

30 minutes go by. During this time, write the following on a blackboard in a way that does not disturb:

Descriptive Attributes - classify a person as to age, sex, marital status, occupation, or any other 'positions' he may occupy.

Behavioral Attributes - describe the way a person acts or can be expected to act, based on his past performance. "Research indicates that a group often is more effective if members have homogeneous descriptive attributes and heterogeneous behavioral attributes."

After 30 minutes, tell them that the meeting is over. Ask them what their decision is. Focus the debriefing discussion on the following questions :

1) At the beginning, how accurately did the prepresenatives speak for their organizations?

2) What conflicts in membership were evident?

3) Who changed positions? Why?

4) How did the group size affect your decision? (sub-group vs. large group).

5) What is the significance of behavioral and descriptive attributes in this exercise?

20 minutes. (Larry and $\mathrm{Jim}$ )

End of class. 


\section{Exercise Roles}

You are the principal of the only high school in town, John F. Kennedy Union High School. You are 62 and plan to retire in 1977.

You are the Chairman of the Board of Education, who was recently elected to a new four-year term.

You are the President of the Chamber of Commerce and an independent businessman with 15 years experience.

You are the President of the P.T.A. at John F. Kennedy Union High School and very active in civic affairs, dating back 3 years.

You are the Executive Director of the local Mental Health Association and a recently retired psychoanalyst.

You are a social worker by profession and work in the local mental health clinic. You are a recent graduate of the University of Chicago School of Social Work and have been in town only 3 months.

You are a P.E. teacher at John F. Kennedy Union High School. The principal has told you that you will teach a proposed Sex Ed class if approved.

You teach Industrial Arts at John F. Kennedy Union High School and strongly believe in vocational training for young people.

You are a member of the P.T.A. from the Gerald R. Ford Elementary School, where 3 of your children attend.

You are the parent of 2 High School students and have always been very vocal about community affairs. You consider yourself a social activist.

You are a catholic parent with 8 children, all school age, and a member of "Concerned Parents for the Moral Preservation of Children."

You are a 50-year old lawyer who is very wealthy and considered a leading citizen in the community.

You are the owner of a large chain of grocery stores, Fred Byers. You are experiencing problems lately with high school kids stealing goods from your stores.

You are a policeman or policewoman who is assigned to the Juvenile Division of the Police Department.

You are a small struggling businessperson who owns a deli.

You are a catholic priest in a predominantly lutheran town.

You are a retired lawyer who is a life member of the ACLU. You have never been married and have no children. 
You are the President of the Student Government at John F. Rennedy Union High School. Your constituents have given you authority to support the proposed recommendation.

Your 10th grade son has just gotten his girl friend pregnant. Only your closest friends know.

You are the most respected AMA doctor in town. The principal has asked you to attend this meeting.

You are a Black father of 2 school age kids -3 and 6 . You are one of only 2 Black families in town. You are a college-educated supervisor at a local defense plant.

You are the President of the Women's Graduate Association. You are married and have $3 \mathrm{kids}-7,4$, and 2 . 


\section{SESSION 4 - NORM DEVELOPMENT}

Purpose of session:

To foster an awareness of what norms are, how they develop; and how they affect goal achievement.

Outline

Discussion of term paper, evaluations, and reading assignment. (Larry)

Class member, who has been coached ahead, comes in late and starts breaking norms. (lateness, loud talking, unrelated topics, etc.) 5 minutes.

Discuss effects of norm breaking. (Jim)

Mini-lecture on definition and significance of norms. 10 minutes. (Larry)

Exercise - The Norms of the Laboratory

Objectives :

1) To develop an awareness of norms by discussing the formal, informal, explicit, and non-explicit norms of the small group skills $1 \mathrm{ab}$.

2) To develop an understanding that norms function to create an order in the group and regulate interaction among the members.

Introduce exercise. Ask class to break into groups of four and give them the task of identifying five positive norms and five negative norms of the class.

15 minutes go by

Class Break

Each group writes the five do's and 5 do not's they have decided upon on the blackboard. The entire class then has a general discussion focused upon the following questions:

1) What norms would you like to change?

2) What are the three norms that help us attain our group goals?

3) What are the three norms that interfer with our goals?

4) Which norms have been instituted by the facilitators? the members?

20 minutes.

End of class. 


\section{SESSION 5 - COMMUNICATION PATTERNING}

Purpose of session:

To develop an understanding of how communication patterns affect goal achievement with a focus upon roles and power relationships.

Outline

Give everyone a chance to look around TV studio.

Exercise 5 - Murder Mystery

Objectives:

1) To give participants an awareness of communication patterns as affected by power relationships and individual roles.

2) To give participants immediate feedback on communication patterns by using video taping as a teaching medium.

3) To develop an awareness of how communication patterns can either help or hinder a group from full utilization of member resources.

Introduce exercise. Split class into 2 groups. Ask for 4 observers. The group is then told that they must solve a murder mystery. They are to discover the murderer, motive, place, and time. Give instructions to observers. 10 minutes.

Have Group 2 go outside of TV studio. Film Group 1 discussion. Pass out clues.

10 minutes go by

Pass out clues. Film Group 2. Have Group 1 leave the TV studio.

10 minutes go by

Bring in Group 1. Play back both groups on videotape. 20 minutes.

Have observers put results on blackboard.

Discussion period. Entire group. Focus around these questions:

1) What role did you play as a member and how did this affect your communication?

2) Who were the influential members? What is the correlation between the number of contributions and amount of influence?

3) How well did your group listen to each other?

4) How would you characterize the communication of your group?

5) Did your group effectively use all of its resources, or were some resources ignored?

6) What did the observers notice as to the quality and quantity of communication?

20 minutes. (Larry and Jim)

End of class. 


\section{SESSION 5 MURDER MYSTERY}

\section{Clues}

1. When he was discovered dead, Mr. Thompson had a bullet wound in his calf and a knife wound in his back.

2. Mr. Barton shot at an intruder in his apartment building at midnight.

3. Mr. Thompson had virtually wiped out Mr. Barton's business by stea1ing his customers.

4. The elevator operator reported to police that he saw Mr. Thompson at $12: 15$ A.M.

5. The bullet taken from Mr. Thompson's calf matched the gun owned by Mr. Barton.

6. Only one bullet had been fired from Mr. Barton's gun.

7. The elevator man sald Mr. Thompson did not seem too badly hurt.

8. A knife found in the parking garage had been wiped clean of fingerprints.

9. Mrs. Scott had been waiting in the lobby for her husband to get off work.

10. The elevator man went off duty at 12:30 A.M.

11. Mr. Thompson's body was found in the park.

12. Mr. Thompson's body was found at 1:20 A.M.

13. Mr. Thompson had been dead for about an hour when his body was found according to the medical examiner.

14. Mrs. Scott did not see Mr. Thompson leave through the lobby while she was waiting.

15. Bloodstains corresponding to Mr. Thompson's blood type were found in the basement parking garage.

16. Police were unable to locate Mr. Barton after the murder.

17. There were bloodstains in the elevator.

18. Mr. Thompson's blood type was found on the carpet outside Mr. Barton's apartment.

19. Mrs. Scott had been a good friend of Mr. Thompson and had often visited his apartment.

20. Mrs. Scott's husband had been jealous of the friendship.

21. Mrs. Scott's husband did not appear in the lobby at 12:30 A.M., the end of his normal working hours. She had to return home alone and he arrived later.

22. At 12:45 A.M. Mrs. Scott could not find her husband or the family car in the basement parking lot of the apartment building where he worked.

\section{Solution}

After receiving a superficial gunshot wound from Mr. Barton, Mr. Thompson stepped on the elevator and was killed by Mr. Scott (the elevator man) with a knife at 12:30 A.M. because Mr. Scott was jealous. 
OBSERVER \#1 - WHO TALKS. . . HOW OFTEN

Directions: Put the person's name outside of the appropriate circle. Make a mark inside the circle every time that person makes a contribution. (One mark per contribution regardless of length). 


\section{OBSERVER \#2 - TYPES OF INTERACTION}

Directions: Put the person's name outside of the appropriate circle. Inside of the circle, make a plus $(t)$ each time a member gives support and a minus ( - ) each time a member interrupts or diverts group discussion. 


\section{SESSION 6 - GOAL SETTING}

Purpose of session:

To develop an understanding of goal elements and an ability to facilitate their achievement.

Outline

Ask if there are any questions about reading or feelings about IV lab experience last week.

Ask for 4 observers. Give them forms and explain. (Jim)

Break class into 4 groups. Explain that the exercise is to define goals for a free class session. They can plan anything they want. The purpose of these small groups is to generate ideas and write clear, specific goals. Begin groups.

20 minutes go by

Pass out feedback forms to each participant. Have observers tally results on board. 5 minutes.

Ask small groups to come together and decide which goals they want to use for the free class period.

20 minutes go by

Class Break

Small groups then reconvene. The discussion can focus upon the following questions :

1) What elements did your group identify as elements in goal setting?

2) How effectively did your group use feedback in formulating goals?

3 ) What problems did you have in first stating your goals? Why?

4) How did your goals change after discussions?

5) How honest were you in stating your goals?

20 minutes. (Larry and Jim float around to all group).

End of class. 
SESSION 6 OBSERVER FORM

Behavior

Tallies

Person - Oriented

Behaviors

Defends self

Deflates others

Off subject

Provokes tension

Group - Oriented

Behaviors

States problem

Clarifies problem

Develops alternative

solutions

Attempts to

harmonize points

of view

Tests consequences 
SESSION 6 PARTICIPANT FEEDBACK FORM

GOALS

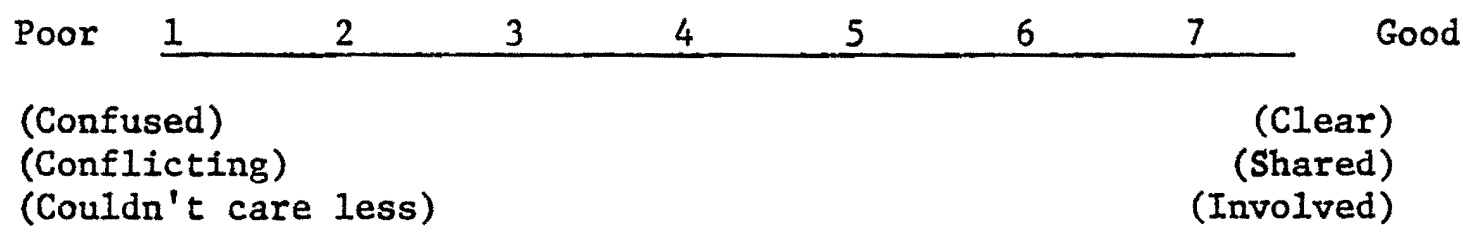

\section{PARTICIPATION}

Poor $\begin{array}{llllllll}1 & 2 & 3 & 4 & 5 & 6 & 7 & \text { Good }\end{array}$

(Few dominate)

(Al1 participate)

(Some passive)

(Al1 listened to)

(Some not listened to)

FEELINGS

Poor $\begin{array}{llllllll}1 & 2 & 3 & 4 & 5 & 6 & 7\end{array}$

(May not express feelings)

(Express responses honestly) 


\section{SESSION 7 - LEADERSHIP STYLE AND AUTHORITY DEVELOPMENT}

Purpose of session:

To focus upon leadership style and its influence upon goal achievement.

Outline

Attendance, questions, and any comments about being in the TV lab. (Larry)

Exercise - Three Styles of Leadership

Objectives

1) To develop an awareness of three leadership styles (autocratic, democratic, and laizze-faire).

2) To become knowledgeable about how different leadership styles affect communication and goal achievement.

3) To provide immediate feedback upon leadership styles, how they affect group style, and productivity by using videotaping.

Divide the class into 3 sub-groups. Explain that there will be situations and 3 leadership styles. $(\mathrm{Jim})$. Ask for 3 observers. Explain forms. 5 minutes. (Larry)

After Group 1 gets into position, read the following situation and give the following leadership role to second person on left.

\section{Situation:}

You are all student representatives on the P.S.S. Board which makes decisions regarding student houseing. There is a crises in the housing finances. Your committee has two alternatives: 1) you can raise everyone's rent by $\$ 75.00$, or close one bullding that has 100 students. Some of you live in the building that might be closed and you all have friends that will be affected by either alternative. Today you must decide:

Raise everyone's rent or close one bullding.

Leadership role: Read this and do not tell the group your role. Pou are to be an autocratic leader. You are to guide the group in a directive fashion. You must make your opinions and beliefs clear and really take responsibility for the work the group accomplishes. Feel free to control the group in any way you wish. They are "your" group.

Film Group 1 for 10 minutes.

After Group 2 gets into position, read the following situation and give the leadership role to the second person on right.

\section{Situation:}

Your political science professor has just assigned your class a fifth book for the quarter. As a group of students, you have begrudgingly 
accepted the first four, but no longer feel complacent about another book to read during finals. You are meeting as a group to decide upon a strategy as to whether or not you want to accept or reject this assignment.

Leadership role: Read this and do not tell the group your role. You are to be a democratic leader. It is your job to see that rules of fair play are observed. Everyone must be given a choice in all of the decisions or procedures in the group. You are not to push your ideas through and you should not let any individuals push theirs without full attention to each member. One person. = one vote.

Film Group 2 for 10 minutes.

After Group 3 gets into position, give them the following situation and hand leadership role to second person on left.

\section{Situation:}

You are all scholarship students at PSU. You have just learned that the Federal Government has not funded one of your scholarships, however, they have not decided which specific student. You are meeting as a group to make this decision today. Each of you is carrying a full-time load and has no other means of financial support. You must announce your decision this afternoon to the project director.

Leadership role: Read this and do not tell the group your role. You are to be a laissez-faire leader. This means that you let happen whatever the group wants. You are not to lead, control, or direct the group in any way. The group may use the time in any way they wish and you are not to take an active leadership role no matter what the group may want.

Film Group 3 for 10 minutes.

\section{Class Break}

Play back all three groups on videotape without interruptions. 30 minutes.

Entire class feedback and discussion.

1) What style of leadership did you see evident in your group?

2) How did the style affect:
a) communication
b) resource utilization
c) decision-making
d) expression of feeling
e) goal achievement

20 minutes.

3) How did the 3 leaders feel about their roles? their groups?

End of class. 


\section{SESSION 8 - PROBLEM-SOLVING}

Purpose of session:

To give participants an understanding of the dynamics and meaning of group problems and solutions in order to facilitate goal achievement.

Outline

Attendance, questions about reading, collect term papers. 10 minutes. (Larry)

Exercise

Objectives :

1) To foster an awareness of the elements of group problem-solving in a difficult situation.

2) To bring out issues of controversy and compromise.

Introduce exercise and set the stage by reviewing the basic situation of being stranded in the desert and the urgent necessity of making a decision about what course of action would be best for the group's survival. State the objectives of the exercise. (Jim)

Divide the class into two groups of eight. Distribute the situation sheets to each group member. After they have read this sheet, review that there are two decisions which they must make: 1) whether to walk out or stay with the bus, and 2) whether or not to hunt for food. Tell the groups to begin. They have 45 minutes. (Larry)

45 minutes go by

Stop the group discussions and hand out the Post-Decision Reaction Form to each person. ( 5 minutes). Then collect forms.

\section{Class Break}

Compute group means and put results on blackborad. (Larry)

Following this, have entire class debrief around the following questions:

1) Discuss reaction sheets

2) How did the group handle controversy?

3) What was the pattern of communication?

4) What was the method by which the group made its decision? Why?

5) What did you learn about aspects of problem-solving?

20 minutes. (Larry and $\mathrm{Jim}$ )

End of class. 
STRANDED IN THE DESERT EXERCISE

Situation

You are one of eight members of a geology club that is on a field trip to study unusual formations in the New Mexico desert. It is the last week in July. You have been driving over old trails, far from any road, in order to see out-of-the-way formations. At 10:45 A.M. the specially equipped minibus in which your club is riding overturns, rolls into a fifteen- to twenty-foot ravine, and burns. The driver and the professional advisor to the club are killed. The rest of you are relatively uninjured.

You know that the nearest ranch is approximately forty-five miles east of where you are. There is no other place of habitation closer. When your club does not report to its motel that evening, you will be missed. Several people know generally where you are, but because of the nature of your outing, they will not be able to pin-point your exact whereabouts.

The area around you is rather rugged and very dry. You heard from a weather report before you left, that the temperature would reach 110 degrees making the surface temperature 130 degrees. You are all dressed in light-weight, summer clothing, although you do have hats and sunglasses. Before your minibus burned, you were able to salvage the following items:

Magnetic compass

Large, light-blue canvas

Book, Animals of the Desert

Rearview mirror

One flashlight

One jacket per person
Accurate map of the area A .38-calibar pistol, loaded Bottle of 1,000 salt tablets Four canteens, each containing two quarts of water

The group needs to make two decisions: (1) to stay where it is or to try to walk out, and (2) to hunt for food or not to hunt. To make these decisions, it will be necessary to rank the salvaged items in the order of their importance. And in making the group decisions, your group must stay together. 
STRANDED IN THE DESERT EXERCISE

Post-Decision Reaction Form

1. What did your group decide?

stay where you are hunt walk out not to hunt could not decide could not decide

2. How understood and listened to did you feel in the group? Not at all $1: 2: 3: 4: 5: 6: 7: 8: 9: 10$ completely

3. How much influence do you feel you had on the group's decision? None at all $1: 2: 3: 4: 5: 6: 7: 8: 9: 10$ complete

4. How responsible and committed do you feel to the decisions that were made? Not at all $1: 2: 3: 4: 5: 6: 7: 8: 9: 10$ completely

5. How satisfied are you with your group's performance?

Very dissatisfied $1: 2: 3: 4: 5: 6: 7: 8: 9: 10$ Very satisfied

6. I would assess my learning about the issue under discussion to be: None at all $1: 2: 3: 4: 5: 6: 7: 8: 9: 10$ A great deal

7. Write two adjectives describing the way you now feel. 


\section{SESSION 9 - STUDENT-LED SESSION \\ FOCUS - TRUST-BUILDING}

Activities:

1) Trust Circle (2 groups of 8 people)

2) Group Fantasy. This was a creation of 2 of the students which included everyone relaxing with eyes closed and one student directing a fantasy around feelings of loneliness and harmony within one's self.

3) Social Time. Students brought a variety of snacks and the entire class spent time eating and talking to one another in an informal atmosphere.

4) Trust Circle

Evaluation of Goals:

The students wanted to foster trust in this session. Thus, they asked everyone to notice if there was any difference in the way they felt in doing the trust circle the first of class and then at the end. Most everyone reported that they were much more trusting and relaxed in the second trust circle. 


\section{SESSION 10 - EVALUATION}

Purposes of class:

To gather data and feedback from the students.

To return term papers.

Outline

Pass out Post-Lab Evaluations. Ask if there are any questions. Tell them they can use as much as two hours to complete the form.

Upon completion of form, hand back term papers.

End of class. 
APPENDIX B 
Course Outline

Course Objectives:

1) to develop a theoretical understanding of how small groups work.

2) to practice identified skills within the following areas of small groups; goal setting problem-solving, leadership style, norm development, membership utilization, and communication patterning.

3) to gain an understanding of one's own individual style within small groups, both as a member and as a leader.

4) to experience and understand group development and group process as it occurs within the $1 \mathrm{ab}$.

Grading and Assignments:

The course is designed to provide a focus for students interested in developing skills, within the small group. Therefore, each class session will feature a mini-lecture and a laboratory experience aimed at skill development. Students will be expected to participate in these laboratory exercises each week.

The course text will be Groups: Theory and Experience, by Rodney Napier and there will be weekly reading assignments in this text. Also, a number of readings are listed in the biblography for those students desiring further study.

The grading will be decided on two things. First, active class attendance and participation will guarantee the grade of $C$. Those interested on obtaining a higher grade will be required to write a term paper.

\section{Term Paper}

This assignment is due on March 1, 1976. The paper should be typed and not more than ten pages in length. Possible topics might include the following:

1) Observe a small group and write a description/analysis of your observation. Use one or more of the class topics and bibliographic references to support your analysis.

2) Evaluate your group skills in terms of the six skills presented in this lab. Use the readings to support your evaluation.

3) Describe a group situation in which you are participating or have participated, and analyze its process and development. Note your role in this group and how you influenced positively or negatively - its development. Use the readings to support your paper.

4) Interview 3 or more members of a particular group. Report on their perceptions relevant to the content areas (skills) discussed in lab. Use the reading to support your paper. 
The grade on your paper will be made up of two parts. The first part, which equals $75 \%$ will be content. The second part, which equals $25 \%$, will be on style and organization. The content part will include: How thoroughly you have presented, developed, and substantiated the main ideas of your paper and utilized bibliographic resources. The styles and organization part will include: syntax, spelling, and cohesiveness. 


\section{Weekly Topics and Reading Assignments}

January 12-Introduction to course.

January 19-Group Development. The purpose of this session will be to gain an understanding of how groups develop through time. The lab experience will focus on students being able to practice identifying group stages. Reading Assignment: Napier, Chapter 7.

January 26-Membership Utilization. The purpose of this session is to develop an understanding of the importance of the selection and composition of group membership. The exercises will foster an awareness of the unique characteristics of each group member. Participants will have a chance to see how their own characteristics can maximize group and individual goal achievement.

Reading Ass1gnment: Napier, Chapter 2.

February 2-Norm Development. The purpose of this session will be to understand what norms are, how they develop, and how they influence goal achievement. Exercises will be aimed at defining how communication and leadership style affect group norms. Participants will learn to identify. norm development and influence norms to attain group goals. Reading Assignment: Napier, Chapter 3.

February 9-Communication Patterning. The purpose of this session will be to develop an understanding of how communication patterns affect group goal achievement. Lab exercises will aim at giving participants experiences in examining communication patterns as affected by individual roles and power relationships. Participants can gain an understanding of how their own role and status affect their group participation.

Reading Assignment: Napier, Chapter 1.

February 16-Goal Setting. The purpose of this session will be to formulate an understanding of goal elements and facilitating their achievement. Lab exercises will help students identify these elements and how to achieve goal-setting in groups. Participants will have a chance to identify goal elements through experiential exercises and later compare their experience against a theoretical background.

Reading Assignment: Napier, Chapter 4.

February 23-Leadership Style \& Authority Development. This session will focus on leadership process for influencing goal attainment. Lab exercises will center around different styles of group leadership, and will offer participants a chance to observe and practice different leadership styles. Reading Assignment: Napier, Chapter 5.

March 1-Problem-Solving: In this session, our purpose will be aimed at understanding the dynamics and meaning of group problems and solutions in 
order to facilitate goal achievement. Exercises will involve the resolution of a group problem and how it affects group development and goal achievement. Participants can gain an appreciation for their own problemsolving style as an individual and group member.

Reading Assignment: Napier, Chapter 6 .

March 8-Free. The purpose of this session will be negotiated between the instructors and students.

March 15-Evaluation of Lab and Instructors. Feedback from students and instructors. 


\section{Supplemental B1bliography}

1. Berstein, Saul (ed.), Further Explorations in Group Work. (Boston, Mass: Boston University Bookstore). 1970.

2. Cartwright, Dorwin and Zander, Alvin, Group Dynamics: Research and Theory. 1970.

3. Dyer, William, Modern Theory and Method in Group Training. (New York: Van Nostrand Relnhold). 1972.

4. Feldman, Ronald A. and Wodarski, John S., Contemporary Approaches to Group Treatment. (San Francisco: Jossey-Bass Publishers). 1975.

5. Frey, Louise A. and Rolodny, Ralph L., "Illusions and Realities in Current Soclal Work with Groups.", Soctal Work. 9:80-89. April, 1964.

6. Gibbard, Graham S.; Hartman, John J.; and Mann, Rfchard D., Analysis of Groups. (San Francisco: Jossey-Bass Publishers). 1974.

7. Glasser, Paul; Sarri, Rosemary; and Vinter, Robert (eds.), Individual Change Through Small Groups. (New York: The Free Press). 1974.

8. Goldberg, C. and Goldberg, M., The Human Circle. (New York: NelsonHa11). 1973.

9. Golemblewski, Robert T. and Blumberg, Arthur, Sensitivity Training and the Laboratory Approach. (Itasca, Illinois: F.E. Peacock). 1970.

10. Hartford, Margaret, Groups in Social Work. (New York: Columbia University Press). 1972

11. Bartford, Margaret, "The Preparation of Soclal Workers to Practice With People in Groups." Journal of Education in Soclal Work. $3(2): 49-60$.

12. Hopkins, Terence K., The Exercise of Influence in Small Groups. (Totowa, New Jersey: The Bedminister Press). 1964.

13. Kelly, William, "Group Training: Perspectives of Professional Trainees on Group Dynamics," Small Group Behavior. 5(4), November 1974.

14. Klein, Alan F., Social Work Through Group Process. (Albany, New York: N.Y. State University Press). 1970

15. Konopka, Gisela, Soclal Group Work: A Helping Process. (New Jersey: Prentice Hall). 1963. 
16. Lawrence, Harry and Sundel, Martin, "Self Modification In Groups: A Student Tralning Method for Social Groupwork," Journal of Education in Social Work, $11(2): 76-83$. Spring, 1975.

17. Leavitt, H. and Mueller, R., "Some Effects of Feedback on Communication," Human Relations. 4:401t, 1951.

18. Maier, Norman R., Problem Solving Discussions and Conferences: Leadership Methods and Skills. (New York: McGraw-H111 Book Co.). 1963.

19. Malcom, Andrew, The Tyranny of the Group. (Totowa, New Jersey: Littlefield, Adams and Co.). 1975.

20. Milson, Fred, An Introduction to Group Work Sk111. (London: Routeledge \& Regan Paul Co.). 1973.

21. Murphy, Marforie, The Social Work Group Work Method in Social Work Education. A Project Report of the Cirriculum Study, XI. (New York: Council on Soctal Work Education). 1959.

22. Napier, Rodney W. and Gershenfeld, Matt1, Groups: Theory and Experience. (Boston, Mass.: Houghton-Mifflin Co.). 1973.

23. Northern, Helen, Social Work with Groups. (New York: Columbia University Press). 1969.

24. Papell, Catherine and Rothman, Beulah, "Social Group Work Model: Possession and Heritage," Journal of Education in Social Work. II: $66-77.1966$

25. Phillps, Gerald and Erickson, Eugene, Interpersonal Dynamics in the Sma11 Group. (New York: Random House). 1970.

26. Phillips, Helen V., Essentials of Soclal Group Work Skill. (New York: American Book-Stratford Press, Inc.). 1957

27. Rogers, Car1, Car1 Rogers on Encounter Groups. (New York: Harrow Books, Inc.). 1970.

28. Rosenfeld, Lawrence B., Human Interaction in the Small Group Setting. (Columbus, Ohio: Charles E. Merrill Co.). 1973.

29. Schwartz, William, "Soclal Group Work: The Interactionist Approach," Encyclopedia of Soclal Work. (Albany, New York: Boyd Printing Co.).

30. Shaw, M., "Communication Networks, in L. Berkowitz (ed.), Advances in Experimental Social Psychology. Vol. I. (New York: Academy Press).

31. Silverman, M., "Knowledge in Soclal Group Work: A Review of the IIterature," Soctal Work. 11(3): 56-62. 1966. 
32. Thompson, Sheila and Kahn J., The Group Process as a Helping Technique. (New York: Pergamon Press, Inc.). 1970.

33. Tropp, Emanuel, "Social Group Work: The Developmental Approach," in R. Morris (ed.), Encyclopedia of Social Work. (New York: National Association of Soctal Workers). Vol. II, 1971.

34. Tropp, Emanuel, "The Group: In Life and Soclal Work," Soclal Casework. 49: 267-74. May, 1968.

35. Tuckman, B., "Developmental Sequences in Small Groups," Psychological Bulletin. 63:384-399. 1965.

36. Vinter, Robert (ed.), Readings in Group Work Practice. (Ann Arbor, Michigan: Campus Publishers). 1967 


\section{Pre-Evaluation Questionnaire}

We are giving you this questionnaire to help us teach and evaluate this lab. Your answers will tell us "where to begin" and help us evaluate our teaching model at the end of the term. Your responses w111 not affect your grade nor participation as a student.

Please respond to the following questions as completely and honestly as you can. If you have any questions about this questionnaire, please ask us before you leave today. Thanks!

Your name:

Date:

(1) What year student are you at PSU?

(2) Are you a full-time or part-time student?

(3) List any small group experience which you have had as a member or leader within the past three years. Please indicate whether you were a group leader or member. What kind of group (e.g., encounter, staff combittee, recreational, etc.)? How long did it last?

(4) What do you want out of this lab?

Described below are six situations which sometimes occur in human interaction groups. Imagine yourself as a member of such a group and respond to each situation as asked.

(1) Your human interaction group is meeting for the first time today. All ten members who are your peers introduce themselves and begin talking about the group's goals. After an hour of non-productive discussions, the group cannot decide on any goals. You then decide to facilitate the group's goal setting. What do you do? 
(2) Your group has just finished its first session. As you leave the group, you reflect on yourself as a group member. If you were to describe your group, how. would you describe its membership?

(3) You are arguing with a group member about a statement you have made. You want to resolve this argument in the group; however, you are not sure whether he understands your point of view. How can you facllitate the communication between yourself and this nember?

(4) During the fifth meeting, two members arrive twenty minutes late. This is the second time that each of them has been late. One of them is a "tangential talker" who constantly leads the group discussion away from its goal activity. You want to address the group about these members. How do you do it?

(5) You have just been appointed leader for the elghth meeting of your group. During this meeting, three members begin to attack verbally another member who claims to dislike the group's activity. At the present moment, their interaction is intensifying: he denies their Increasing accusations; they criticize his remarks. What do you do, if anything?

(6) During the tenth meeting, your group learns that its meeting place will not be avallable for any further meetings-effective next week for the following meeting. Several members have offered ideas, but the group does not accept them. You decide to suggest a process for solving this problem. What do you do? 
Using your own group experience or personal feeling, circle the number which best represents your skill rating for each question. " 1 " - low, "3" - moderate, "5" - high. For each skill, a definition follows which standardizes our understanding of its meaning. Rate yourself according to each definition.

(1) Goal-Setting - understanding the elements of goals and facilitating their achievement.

Low High

1 2 3 4 5

(2) Membership - utilizing group selection and composition in an effort to maximize group attractiveness and effectiveness for goal attainment.

Low High

1 2 3 4 5

(3) Communication - recognizing and understanding interpersonal communication principles to facilitate goal achievement.

Low High

1 2 3 4 5

(4) Norm Development - recognizing and influencing group norms in a way which facilitates goal attalnment.

Low High

1 2 3 4 5

(5) Leadership style and Development of Authority - understanding leadership process as well as the development of authority for influencing goal achlevement.

Low High
1
2
3
4
5

(6) Problem-Solving - understanding the dynamics and meaning of group problems and solutions in order to remove goal achlevement barriers.

Low High 


\section{Post-Lab Evaluation}

\section{Your Name:}

This evaluation will help us evaluate the Lab in terms of its content objectives, the effectiveness of the teaching method used, the student requirements, and changes which you feel need to be made in future Labs. Your responses will not influence your grade. Although we will match your response with your pre-evaluation questionnaire, you identity will be anonymous in our practicum write-up.

1) Rate the overal1-quality of the Lab exercises (circle one of the following):

$$
\text { Excellent Good Fair Poor }
$$

2) a. What exercises did you like best?

b. What exercises did you like least?

3) The purpose of this Lab was for you to learn new group skills and/or improve ones you already had. If you think this purpose was achieved for you, then list those new and/or 1mproved skills which resulted from your participation in the Lab. If you think you haven't learned new skills or Improved old ones, don't answer this question.
a. New skills -

b. Improved skills -

4) During two Lab sessions, the TV was used as a supplementary teaching aid. How would you judge its effectiveness in your learning new group skills (circle one):

$$
\text { Excellent Good Fair Poor }
$$


5) How would you rate the instructors' handling of Lab sessions (circle one):

Excellent Good Fair Poor

6) In answering the next responses on instructor behavior, please use the following criteria:

Excellent (E) - Instructors consistently exceed your expectations in a superior manner.

Good (G) - Instructors consistently exceed your expectations.

Pair (F) - Instructors consistently meet your expectations.

Poor (P) - Instructors consistently do not meet your expectations.

Also, please base your response to each question on your individual subjective judgment rather than on what you belleve other students in the Lab might think.

Circle one.

a. Takes an active and personal interest in the Lab. $E$ G $F$

b. Facilitates student's potential in learning group ski11s.

E $\quad$ G $\quad$ F $\quad$ P

c. Stressed important group skills.

E $\quad$ G $\quad F \quad P$

d. Achleved course objectives as outlined in course description.

E $\quad$ G $\quad F \quad P$

e. Are accessible to individual students.

E $\quad G \quad F \quad P$

f. Were clear and understandable in explanations of group skills and exercises.

E $\quad$ G $\quad F \quad P$

g. Presented Lab materlal-exercises, bibliography, course outline and description-in a well-organized fashion.

E $\quad \begin{array}{lll}\mathbf{G} & \mathbf{F} & \mathbf{P}\end{array}$

h. Were responsive to student requests.

E $\quad$ G $\quad$ F $\quad$ P

i. Helped students identify relationship between exercises and skills.

E $\quad$ G $\quad$ F $\quad$ P

7) Do you think the text, Groups: Theory and Experience, should be (circle one):

Continued

On Reserve Only

Discontinued 
8) Was the quantity of the required reading for the Lab generally (circle one):

Too Much About Right Too Little

9) Was the quality of the required reading for the Lab generally (circle one):

Excellent Good Fair $\quad$ Poor

10) If you were teaching this Lab, how would you plan the reading?

Select one of the following?

No Required Reading

Required Text

Required Readings from Bibliography

Required Text and Readings from Bibllography

11) Assess the written term paper for the Lab in terms of:

a. grading (blanket " $C$ " and content/style format)

b. the value of a written paper for integrating Lab theory. (Use the reverse side if you wish).

12) If you were to teach this Lab, what things would you change?

13) What things would you not change?

14) In general, rate your level of satisfaction with this course, 1.e., the degree to which your expectations for the Lab were net (circle one):

Very satisfied Satisfled So-So Dissatisfled Very dissatisfied

15) Additional comments, suggestions, criticisms. 
Described below are six situations which sometimes occur in human interaction groups. Imagine yourself as a member of such a group and respond to each situation as asked.

(1) Tour human interaction group is meeting for the first time today. All ten members who are your peers introduce themselves and begin talking about the group's goals. After an hour of non-productive discussions, the group cannot decide on any goals. You then decide to facilitate the group's goal setting. What do you do?

(2) Your group has just finlshed its first session. As you leave the group, you reflect on yourself as a group member. If you were to describe your group, how would you describe its membership?

(3) You are arguing with a group member about a statement you have made. You want to resolve this argument in the group; however, you are not sure whether he understands your point of view. How can you facilitate the communication between yourself and this member?

(4) During the fifth meeting, two members arrive twenty minutes late. This is the second time that each of them has been late. One of them is a "tangential talker" who constantly leads the group discussion away from its goal activity. You want to address the group about these members. How do you do it?

(5) You have just been appointed leader for the eight meeting of your group. During this meeting, three wembers begin to attack verbally another member who claims to dislike the group's activity. At the present moinent, their interaction is intensifying: he denies their increasing accusations; they criticize his remarks. What do you do, if anything? 
(6) During the tenth meeting, your group learns that its meeting place will not be avallable for any further meetings-effective next week for the following meeting. Several members have offered ideas, but the group does not accept them. You decide to suggest a process for solving this problem. What do you do?

Using your own group experience or personal feeling, circle the number which best represents your skill rating for each question. "1" - low, "3" - moderate, "5" - high. For each skill, a definition follows which standardizes our understanding of 1ts meaning. Rate yourself according to each definition.

(1) Goal-Setting - understanding the elements of goals and facilitating their achievement.

Low High

1 2 3 4 5

(2) Membership - utilizing group selection and composition in an effort to maximize group attractiveness and effectiveness for goal attainment.

Low High

1 2 3 4 5

(3) Communication - recognizing and understanding interpersonal commun1cation principles to facilitate goal achievement.

Low High

1 2 3. 4 5

(4) Norm Development - recognizing and Influencing group norms in a way which facilitates goal attainment.

Low High
1
2
3
4
5

(5) Leadership Style and Development of Authority - understanding leadership process as well as the development of authority for influencing goal achievement. 
(6) Problem-Solving - understanding the dynamics and meaning of group problems and solutions in order to remove goal achievement barriers.

Low

High

1

2

3

4

5 


\section{BIBLIOGRAPHY}

Appelbaum, Stephen A. "The Pleasure and Reality Principles in Group Process Teaching." British Journal of Medical Psychology, XXXVI (1963), 49-56.

Bales, R. F., and Strodtbeck, F. L. .. "Phases in Group Problem Solving." Journal of Abnormal and Social Psychology, XIVI, (1951), 485-495.

Bennis, Warren G. Organizational Development: Its Nature, Origins and Prospects. Reading: Mass: Addison-Wesley Pub. Co., 1969.

Berger, I. I. "Group Psychotherapy Institutes: group process, therapy, or resistance to learning?" International Journal of Group Psychotherapy, XVII (1967), 505-512.

Bernstein, Saul. (ed.). Further Explorations in Group Work. Boston, Mass: Boston University Bookstores, 1970.

Bolman, Lee. "Some Effects of Trainers on Their T Groups." Journal of Applied Behavioral Science, VII (1971), 309-325.

Burian, William A. "The Laboratory As An Element in Social Work Curriculum Design," Journal of Education for Soclal Work, XII (1976), 36-43.

Cartwright, Dorwin and Zander, Alvin. Group Dynamics: Research and Theory. New York: Harper \& Row, 1968.

Coffee, H. S. "Soclo and Psyche Group Process: Integrative Concepts." Journal of Social Issues, VIII (1952), 65-74.

Coyle, Grace L. Group Experience and Democratic. New York: Association Press, 1947.

Delameter, John. "A Definition of Group." Smal1 Group Behavior, V (February, 1974), 30-44.

Deutsch, Rarl. The Nerves of Government. New York: The Free Press of Glenco, 1963.

Dies, Robert R. "Attitudes toward the training of group psychotherapists." Small Group Behavior, V (February, 1974), 65-79.

Dyer, William. Modern Theory and Method in Group Training. New York: Van Nostrand Reinhold, 1972.

Feldman, Ronald A., and Wodarsk1, John S. Contemporary Approaches to Group Treatment. San Francisco: Jossey-Bass Publishers, 1975.

Frey, Louise A., and Kolodny, Ralph L. "Illusions and Realities In Current Social Work with Groups," Soclal Work, IX (April, 1964), 80-89. 
Gibbard, Graham S., Hartman, John J. \& Mann, Richard D. Analysis of Groups. San Francisco, Ca: Jossey-Bass Pub. 1974.

Glasser, Paul; Sarri, Rosemary; and Vinter, Robert. (eds.). Individual Change Through Small Groups. New York: The Free Press, 1974.

Goldberg, C., and Goldberg, M. The Human Circle. New York: Nelson-Hall, 1973.

Golembiewski, Robert T., and Blumberg, Arthur. Sensitivity Training and the Laboratory Approach. Itasca, Illinois: F.E. Peacock Co., 1970.

Hartford, Margaret. "The Preparation of Social Workers to Practice with People in Groups." Journal of Education in Soclal Work, III (Fall, 1967), 49-60.

Hartford, Margaret. Groups in Social Work. New York: Columbia University Press. 1972.

Hearn, Gordon. "Theory of Small Group Behavior," Unpublished Manuscript, School of Social Work, Portland State University, 1973.

Homans, George Caspor. Social Behavior: Its Elementary Forms. New York: Harcourt, Brace \& World, 1961.

Homans, G. C. The Human Group. New York: Harcourt, Brace \& World, 1950.

HopkIns, Terence $K$. The Exercise of Influence in Small Groups. Totowa, New Jersey: The Bedminister Press. 1964.

Horwitz, Leonard. "Tralning Groups for Psychiatric Residents." International Journal of Group Psychotherapy, XXII (October, 1972), 421-435.

Johnson, David W., and Johnson, Frank P. Joining Together: Group Theory and Group Skills. Englewood Cliffs, New Jersey: Prentice-Hall, Inc. 1975.

Kelly, William. "Group Training: Perspectives of Professional Trainees on Group Dynamics.". Small Group Behavior, V (November, 1974).

Kelman, н. C. "Compliance, Identification \& Internalization." Journal of Conflict Resolution, II (1958), 51-60.

Klein, Alan F. Social Work Through Group Process. Albany, New York: New York State University Press. 1970.

Rlein, Josephine. The Study of Groups. London: Routledge \& Paul. 1956.

Konopka, Gisda. Social Group Work: A Helping Process. New Jersey: Prentice Ha11, 1963. 
Lakin, Martin; Lieberman, Morton A.; and Whitaker, Dorothy S. "Issues in the Training of Group Psychotherapists." International Journal of Group Psychotherapy, XVIII (1969), 307-325.

Lawrence, Harry, and Sundel, Martin. "Self-Modification in Groups: A Student Training Method for Social Groupwork." Journal of Education for Social Work, II (Spring, 1975), 76-83.

Leavitt, H., and Mueller, R. "Some effects of feedback on communication." Human Relations, IV (1951), 401-411.

Levy, Ronald B. Human Relations - A Conceptual Approach. Scranton, Pennsylvania: International Textbook Co. 1969.

Lieberman, Morton A; Lakin, Martin; and Whitaker, Dorothy S. "Problems \& Potential of Psychoanalytic and Group-Dynamic Theories for Group Psychotherapy." International Journal of Group Psychotherapy, XVIII (1969), $131-141$.

Maier, Henry W. "Application of Psychological and Sociological Theory to Teaching Soctal Worker with the Group." Journal of Education for Soclal Work, III (Spring, 1967), pp. 29-40.

Maier, Norman R. Problem-solving Discussions \& Conferences: Leadership Methods \& Ski1ls. New York: McGraw-Hill Book Co. Inc. 1963.

Malcom, Andrew. The Tyranny of the Group. Totowa, New Jersey: Littlefield, Adams \& Co. 1975.

Marcos, Fred. "The Adopt Learning System." Unpublished Manuscript. Rockville, Maryland: FM Associates, 1973.

Merton, R. K. Soclal Theory and Social Structure. New York: Free Press. 1957.

Mills, Theodore M. The Sociology of Small Groups. Englewood Cliffs, New Jersey: Prentice-Hall. 1967.

Milson, Fred. An Introduction to Group Work Skil1. London: Routledge \& Kegan PauI. 1973.

Murphy, Marjorie. The Social Work Group Work Method in Social Work Education. A Project Report of the Curriculum Study, XI. New York: Counc11 on Social Work Education. 1959.

Napier, Rodney W. \& Gershenfeld, Matt1. Groups: Theory \& Experience. Boston: Houghton Miffin Co. 1973.

Newcomb, T. M. "Social Psychological Theory: Integrating Individual and Social Approaches," in E. P. Hollander and R. G. Hunt (eds.). Current Perspectives in Soclal Psychology. New York: Oxford University Press, 1963, 7-20. 
Northern, Helen. Social Work with Groups. New York: Columbia University Press. 1969 .

Olmsted, Michael S. The Small Group. New York: Random House. 1959.

Papell, Catherine, and Rothman, Beulah. "Social Group Work Models: Possession \& Heritage." Journal of Education for Social Work, II (1966), 66-77.

Parsons, Bales, and Shils, E. E. Working Papers in the Theory of Action. Glencoe, Illinois: Free Press. 1953.

Parsons, T. and Shils, E. A. (eds.). Toward a General Theory of Action. Cambridge, Mass: Harvard University Press. 1951.

Pernell, Ruby. "Identifying and Teaching the Skill Components of Social Group Work," In Faculty Day Conference Proceedings. New York: Council on Social Work Education. 1964.

Philips, Gerald, and Erickson, Euguene. Interpersonal Dynamics in the Small Group. New York: Random House. 1970.

Philips, Helen V. Essentials of Social Group Work Skill. New York: American Book-Stratford Press, Inc. 1957.

Robinson, Virginia P. "The Meaning of Skill," Training for Skill in Soctal Casework. Philadelphia: University of Pennsylvania Press. 1942 .

Rogers, Car1. Car1 Rogers on Encounter Groups. New York: Harrow Books. 1970 .

Rosenfeld, Lawrence B. Human Interaction in the Small Group Setting. Columbus, Ohio: Charles E. Merrill Pub. Co. 1973.

Sarri, Rosemary \& Galinsky, Maeda. "A Conceptual Framework for Teaching Group Development in Social Group Work," in Faculty Day Conference Proceedings, New York: Council on Social Work Education. 1964.

Schmuch, Richard A.', and Miles, Mathew B. Organizational Development in the Schools. California: National Press Books. 1971.

Schopler, Janice H., and Galinsky, Maeda J. "Goals in Social Group Work Practice: Formulation, Implementation; Evaluation," in Individual Change Through Small Groups. ed. by Paul Glasser et al. New York: The Free Press. 1974.

Schwartz, William. "Social Group Work: The Interactionist Approach," Encyclopedia of Social Work. Albany, New York: Boyd Printing Co. II, (1971), 1252-1262.

Shaw, M. "Communication Networks." In L. Berkowitz (Ed.), Advances in Experimental Social Psychology. New York: Academy Press. 1964. 
Shepherd, Clovis R. Small Groups, San Francisco, Calif: Chandler Publishing Co. 1964 .

SherIdan, E. P.; Shack, J.: Waler, R. E.; Egan, G.; and Lavigne, N. "A training program for small-group leaders: overview \& evaluation." Journal of Community Psychology. I (January, 1973), 3-12.

Silverman, M. "Knowledge in Social Group Work: A Review of the Literature." Social Work, XI (1966), 56-62.

Slater, P. "Contrasting Correlates of group size." Sociometry, CXXVIII (1958), 211-217.

Stoller, Frederick H. "The Use of Focused Feedback in Small Groups." in Explorations in Human Relations Training and Research. Maryland: National Training Laboratories, I (1966).

Thomas, Wh. B., and Clay, Mark I. Social Workers in the Community Mental Health Field: A Delphi Forecast of Training Prlorities. Unpublished master's thesis. Portland State University School of Social Work, 1975.

Thompson, Shella, and Kahn J. The Group Process as a Helping Technique. New York: Pergamion Press, Inc. 1970.

Tropp, Emanuel. "The Group: In Life and Social Work," Social Casework, XIVIII (May, 1968), 267-274.

Tropp, Emanuel. "Soclal Group Work: The Developmental Approach," in R. Morris, (ed.). Encyclopedia of Soclal Work, II (1971).

Tuckman, B. "Developmental Sequences in Small Groups," Psychological Bulletin, LXIII (1965), 384-399.

Vicino, Franco L.; Krusell, Jud1th; Bass, Bernard M.; Dec1, Edward L.; Landy, David A. "The Impact of PROCESS: Self-Administered Exercises for Personal \& Interpersonal Development." Journal of Applied Behavioral Analysis, VIII (1969), 737-755.

Vinter, Robert. (ed.). Readings in Group Hork Practice. Ann Arbor, Mich: Campus Publishers. 1967.

Wile, Daniel B.; Bron, Gary D.; and Pollack, Herbert B. "The Group Therapy Questionnaire: An Instrument for Study of Leadership in Small Groups." Psychological Reports, XXVII (1970), 263-273.

Wile, Daniel B. "What do Trainees Learn from a Group Therapy Workshop?" The International Journal of Group Psychotherapy, (Apri1, 1973), 185-203.

Wile, Daniel B.; Bron, Gary D.; and Pollack, Herbert B. "Preliminary Val1dation Evidence for the Group Therapy Questionnaire." Journal of Clinical and Consulting Psychology, XXXIII (1970), 367-374. 
Wilson, Gertrude. "The Social Workers' Role in Group Situations." in Marjorie Murphy, The Social Work Group Work Method in Soclal Work Education. A Project Report of the Curriculum Study. New York: Council on Social Work Education. XI (1959).

Wilson, G. and Ryland, G. Social Group Work Practice: The Creative Use of Group Process. Boston, Mass: Houghton-Miffiln. 1949. 